\title{
Migration, Occupational Identity, and Societal Openness in Nineteenth-Century Belgium*
}

\author{
Bart Van de Putte, ${ }^{* *}$ Michel Oris, Muriel Neven, \\ And Konn Matthijs
}

Summary: This article examines social heterogamy as an indicator of "societal openness", by which is meant the extent to which social origin, as defined by the social position of one's parents, is used as the main criterion for selection of a marriage partner. We focus on two topics. The role first of migration and then of occupational identity in this selection of a partner according to social origin. And in order to evaluate the true social and economic context in which spouses lived, we do not use a nationwide sample but rather choose to examine marriage certificates from eleven cities and villages in Belgium, both Flemish and Walloon, during the nineteenth century. By observing different patterns of homogamy according to social origin we show in this article that partner selection was affected by the relationship between migration, occupational identity and class structure. It seems difficult to interpret all these divergent patterns in terms of modernization. In our opinion the historical context creates a complicated set of conditions reflected in differences in the type and strength of migration and in the sectoral composition and evolution of the local economy. The whole exerts an influence over partner selection.

This article examines social heterogamy as an indicator of "societal openness". We refer to the extent to which social origin, considered as the social position of one's parents, is used as the main criterion to select other people for social interaction, in our case most particularly for the selection of a marriage partner. An important claim of modernization theory is that in response to a range of changes, such as the growth of meritocracy or the decline of parental control, societies tend to become more open so that social origin is less rigidly adhered to as a determinant in partner choice. ${ }^{1} \mathrm{~A}$

\footnotetext{
* The authors would like to thank Etienne van der Straten for his help in the database management, and Anne Jacquemin who made the Liège marriage certificates available.

** Bart Van de Putte is Postdoctoral Fellow of the Fund for Scientific Research - Flanders (Belgium).

I. Marco H.D. van Leeuwen and Ineke Maas, "Social Mobility in a Dutch Province, Utrecht I850-1940”, Journal of Social History, 30 (1997), pp. 619-644.
} 
variant claim is that societal openness at the end of the nineteenth century meant "demographic class formation", ${ }^{2}$ a concept applied, in general, to the declining importance of both objective and subjective differences among the lower classes, for instance in the selection of a partner. According to the class-formation perspective, this modern openness was limited to the lower classes while boundaries between them and the middle class remained strong. ${ }^{3}$

In this article we consider the importance of occupational identities to the evolution of societal openness according to social origin, and try to shed light on the role of migration. The specifically sectoral composition of the economy and the level and type of migration are key elements in the economic and social context of any society. Both factors are perhaps important reasons for the greater complexity of the trend towards "modern" societal openness and why that trend is less linear than is sometimes assumed. In other words, they help to explain why the level of societal openness is dependent on historical context. We include the main criticisms of modernization theory and do not expect to find simple continuous processes, nor any progressive uniformity, ${ }^{4}$ but we wish to understand why real patterns of partner selection diverge from the theoretical trend.

The data consist of marriage certificates from several Flemish and Walloon cities and villages. The advantage of the database is that it allows us to evaluate the social and economic context in which these spouses lived in more detail than we can by using a nationwide sample of "individuals". We present the data and give some background information. We then go on to discuss theoretical issues and empirically explore questions of migration, occupational identity, and social origin. We also discuss the methodology used to examine partner selection according to social origin. This methodology is applied later in our study.

\section{DATA AND CONTEXT}

We have used marriage certificates from civil registration registers which are available for the entire nineteenth century. The certificates contain information about the actual marriage, some demographic history of the spouses and their parents, their occupations, their places of residence, and

\footnotetext{
2. Andrew Miles, Social Mobility in Nineteenth- and Early Twentieth-Century England (Basingstoke [etc.], I999).

3. Jürgen Kocka, "Family and Class Formation: Intergenerational Mobility and Marriage Patterns in Nineteenth-Century Westphalian Towns", Journal of Social History, I7 (1984), pp. 4II $-433,423$.

4. Simon Szreter, Fertility, Class and Gender in Britain 1860-1940 (Cambridge, 1996), pp. 23-29; Steve Hochstadt, Mobility and Modernity. Migration in Germany, 1820-1989 (Ann Arbor, MI, I999).
} 


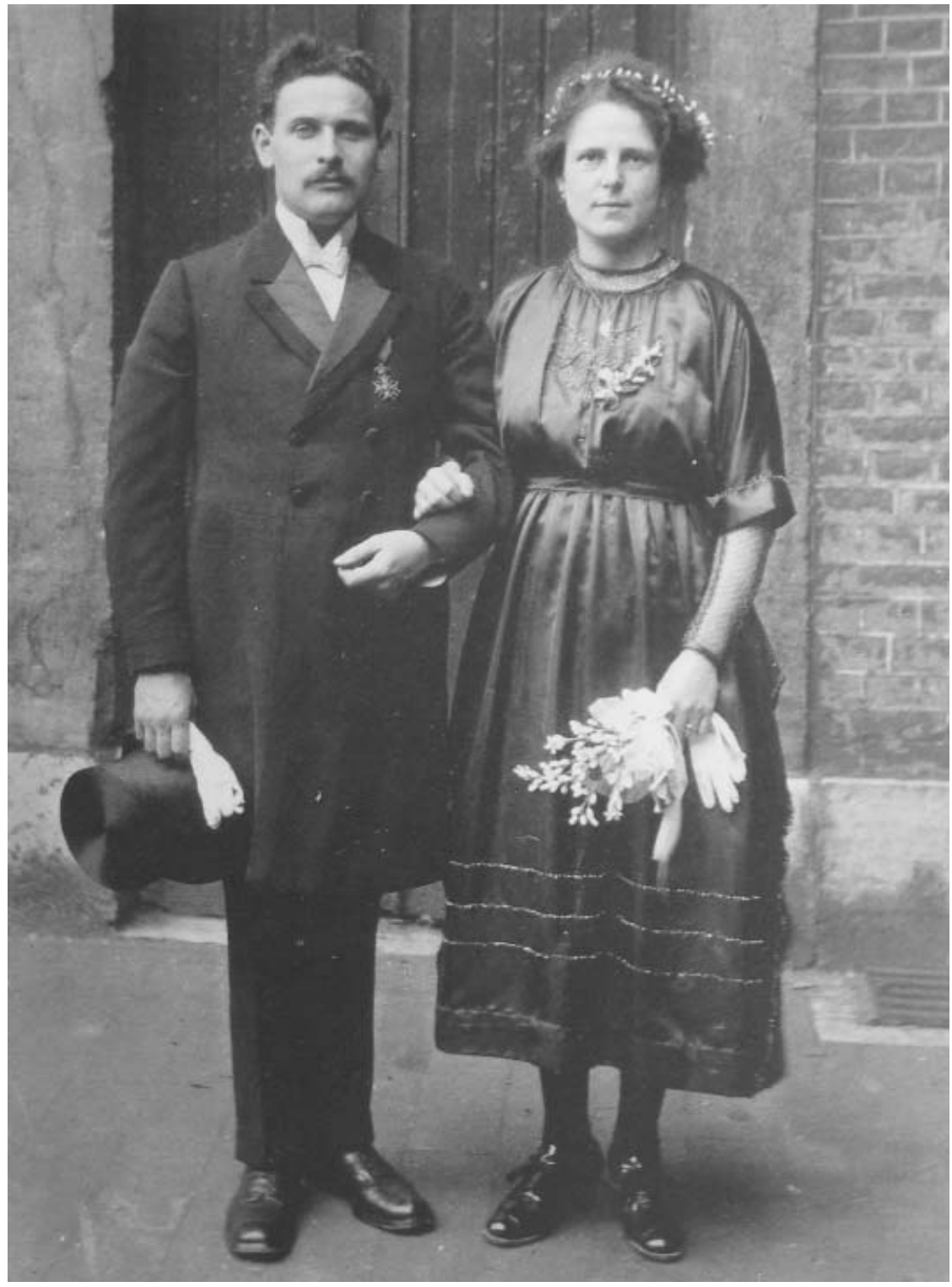

Figure I. Wedding photograph, Liège, c.1880.

E. Van Driessche (ed.), Des accordailles aux épousailles, Galerie CGER, Bruxelles, I9 février-I mai 1988 (Brussels, 1988), p.32. Used with permission. 
so on. Table I gives an overview of the places used for this study. Different sampling strategies were used: for Ghent, one in twelve marriage certificates was included, for Liège one in ten; for Verviers an alphabetical sample was extracted based on the letter B, while for Leuven and Aalst we abstracted one in three marriage certificates. For the other places we included all marriages. Altogether, we have available 38,502 marriage certificates, and in 9, I 52 cases we know the social position of the fathers of both bride and groom.

In the nineteenth century Belgium pioneered industrial revolution on the European continent, but in a highly polarized way. For the cotton and woollen textile industry, Ghent and Verviers were most advanced from the end of the eighteenth century and into the very early nineteenth. Ghent was a large and historic city, its economy based mainly on cotton, though other branches of the textile sector and engineering were important too. In the first half of the nineteenth century its population doubled and migration increased, and with that came a lower standard of living. ${ }^{5}$ In the second half of the nineteenth century population growth slowed. ${ }^{6}$ Unlike Ghent, Verviers was a small centre which underwent a phase of urban crisis similar to Ghent's in the first half of the nineteenth century. ${ }^{7}$ An agglomeration progressively grew along the river Vesdre, and Limbourg was among the last villages to be integrated after 1846 .

Aalst, like Limbourg, participated in a second wave of industrialization. In the first half of the nineteenth century it was a quiet, almost medieval city, where before I880-I 890 factories were still small, with fewer than Io० workers. But from about that time industry expanded, factories became larger, and in both Aalst and Limbourg newly established manufacturers appeared who had to compete with already well-established firms in the big cities, so they exploited their labour forces intensively, imposing working conditions even worse than elsewhere. ${ }^{8}$

Between the almost precocious development of Ghent and Verviers on

5. Chris Vandenbroeke, "Voedingstoestanden te Gent tijdens de eerste helft van de I $9^{\text {de }}$ eeuw", Belgisch Tijdschrift voor Nieuwste Geschiedenis, 4 (1973), pp.109-I69; Peter Scholliers, Wages, Manufactures and Workers in the Nineteenth-Century Factory: The Voortman Cotton Mills in Ghent (Oxford [etc.], 1995).

6. Joël Mokyr, Industrialization in the Low Countries, I795-I850 (New Haven, CT [etc.], 1976), p. 27.

7. Claude Desama and Catherine Bauwens, "Une petite ville au coeur de la révolution industrielle: Verviers et le travail de la laine”, in Bart Van der Herten, Michel Oris, and Jan Rogiers (eds), La Belgique industrielle en I850: deux cents images d' un monde nowveau (Brussels, I995), pp. 87-I 28.

8. Catherine Capron, "Une analyse statistique des migrations à partir d'un registre de population. Application au cas de Limbourg (est de la Belgique), 1847-1866”, in Dominique Barjot and Olivier Faron (eds), Migrations, cycle de vie familial et marché du travail (Paris, 2002), pp. 65-94, 69. 


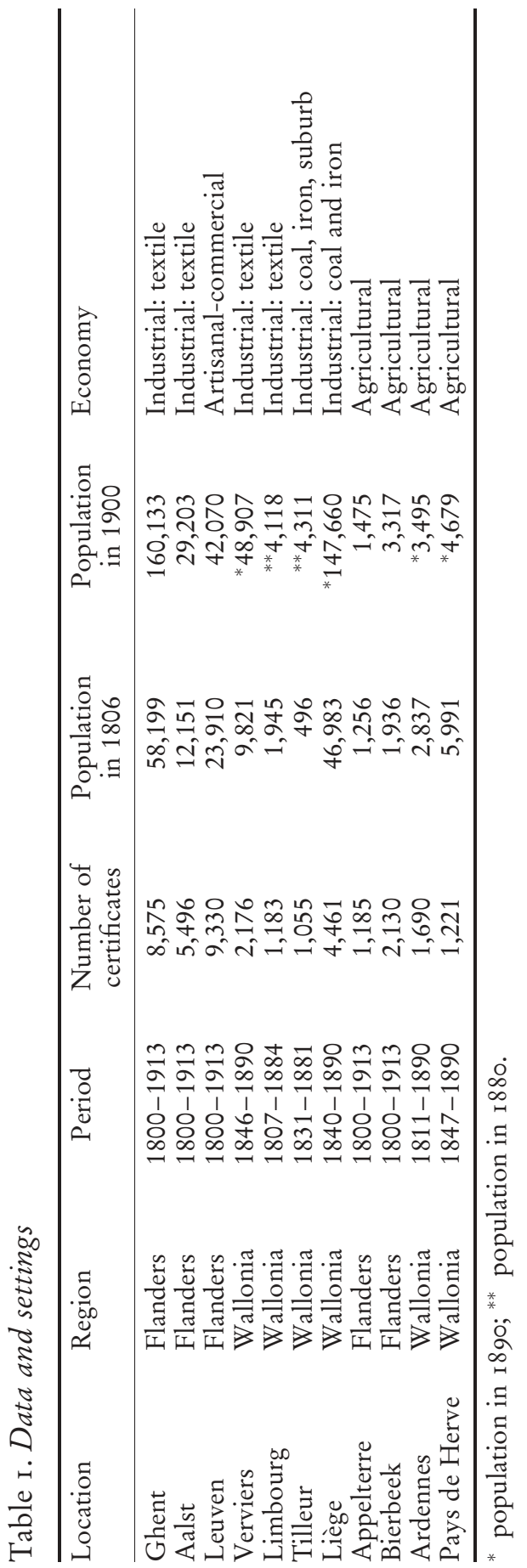


the one hand and Aalst and Limbourg on the other during the I820s, mechanization in the textile industry prompted the modernization of the iron industry, with its coke-fired blast-furnaces, and of coal mining in the area around Liège. Liège itself was a large city, like Ghent, with many professional men and shopkeepers working alongside both old-time artisans, such as weapon-makers, and newer types of worker such as coal miners. 9 As Bairoch pointed out, Liège was a "historical opportunity" since an old town was located right in the centre of a coal basin and attracted a more or less coherent industrial agglomeration around itself. ${ }^{10}$ Tilleur, a small village in which the Society of Sclessin invested in 1828 , and whose population exploded from 6I7 to 6,642 inhabitants between I 83 I and 1900 , is a typical component of the area. ${ }^{\mathrm{II}}$

Like Aalst and Limbourg, Leuven was originally a mid-sized town with no very strong industrialization in the nineteenth century, but Leuven lost the traditional craft and agricultural roots of its economy. ${ }^{12}$ The transition was very gradual and did not lead to many large-scale business enterprises or factories, but Leuven played an important part in administration and education.

Local economic histories find an echo in the socioprofessional profiles of the fathers of grooms, although this echo is altered by geographical and intergenerational social mobility (Table 2). ${ }^{13}$ Liège has a more diverse social structure and, globally, appeared to be a wealthy city with a large elite (I 0.6 per cent of fathers) and few unskilled workers (I 2.2 per cent). Lower managers and professionals were also some I2.5 per cent, and almost half (47.5 per cent) of the fathers in our sample were skilled or semiskilled workers. Leuven presents a similar profile but is obviously a smaller centre. Ghent was more comparable with Liège as an urban centre but had fewer elite citizens and more unskilled workers. In Ghent, in Limbourg, and even more so in Verviers, skilled and semiskilled workers were a large majority. While in Liège this group were mostly craftsmen, in the latter three cities their importance was mainly owing to the textile industry, a sector where production was highly segmented and a corresponding professional vocabulary very well established. Different

9. Anne Jacquemin, "Alliances et reproductions sociales à Liège entre I 840 et I 890 ", in Guy Brunet, Antoinette Fauve-Chamoux, and Michel Oris (eds), Le choix du conjoint (Paris, I998), pp. 107-130, 108-109.

Io. Paul Bairoch, De Jéricho à Mexico. Villes et économie dans l'histoire (Paris, 1985), p. 344. I I. Muriel Neven, "Mortality Differential and the Peculiarities of Mortality in an UrbanIndustrial Population: A Case Study of Tilleur, Belgium”, Continuity and Change, is (2000), pp. 297-329.

I 2. Koen Matthijs, Jan Van Bavel, and Ilse Van de Velde, Lewven in de I 9 de eeuw. De bevolking: een spiegel van het dagelijkse leven (Leuven, 1997).

I3. We chose to use the social position of the fathers as it is the position of the fathers that is used in the analysis of partner selection. 


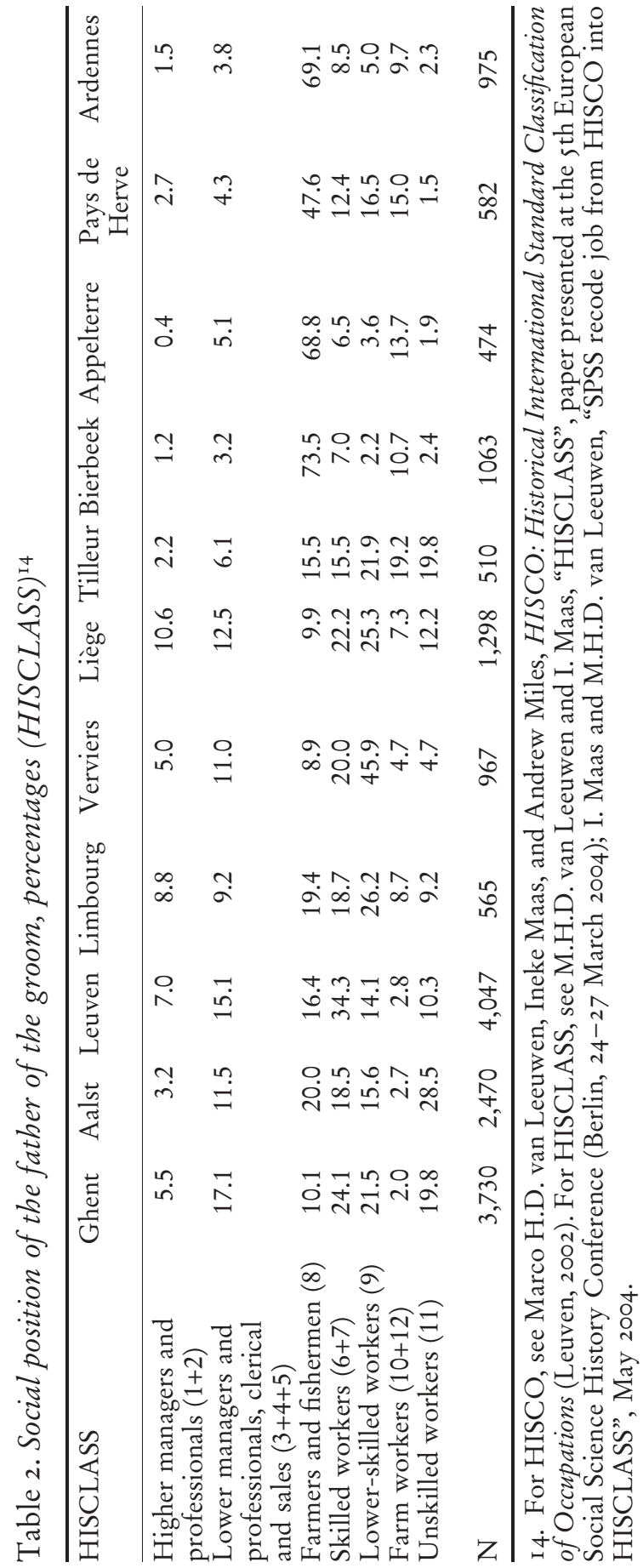


evidence collected in previous studies ${ }^{15}$ contrasts the paternalistic family enterprises of Verviers with the more aggressive and anonymous firms of Ghent and the more recently established manufacturers in Limbourg and Aalst. Indeed, there were few unskilled workers in Verviers, rather more in Limbourg and Ghent, and a lot in Aalst (28.5 per cent). A high level was also observed in Tilleur, where the industrial revolution clearly led to a sort of "dequalification" and an increase in the number of unskilled there. ${ }^{16}$

Our databases cover the Belgian countryside too. Appelterre belongs to a region in which farming was often combined with a domestic textile industry. The cultivation of tobacco was a profitable extra source of income for many inhabitants. Bierbeek is located in a fertile region where farming took place on a fairly large scale. Before the French Revolution abbeys owned large farms, but later those properties came into private hands and were gradually divided up. The Pays de Herve was particularly famous for a very elaborate combination of cattle-breeding and textile proto-industrial production for the merchant-clothiers of Verviers. This area experienced a major collapse of this proto-industry between I 8 IO and I830, and as a result the region "ruralized", with small peasant properties being replaced by large-scale concerns managed by local farmers for urban owners. ${ }^{17}$ In the Ardennes, Sart, and Polleur municipalities was a group of small hamlets on the fringes of Fagnes, some of the poorest ground to be found in Belgium. A majority of semilandless peasants used the large tracts of common land and forests to eke out an existence, which was anyway quite miserable. In the villages farmers were of course the huge majority (69 to 73.5 per cent), except in the Pays de Herve where some 29 per cent of fathers of grooms were classed as skilled or semiskilled workers - a reminder of the area's protoindustrial past. To this must be added that there was no general decrease in the number of farmers.

Nationally, if we compare our samples and Belgium as a whole, we miss several rural areas, the industrial basins of Hainaut, and the capital, Brussels, a major place of interaction between social groups, migrants, and others. ${ }^{18}$ We cannot claim our results are valid for the whole country, but

I5. Capron, "Une analyse statistique"; Desama and Bauwens, "Une petite ville"; Peter Scholliers, De Gentse metalbewerkers in de $19^{\text {de }}$ eeuw: de enquête van L. Varlez (Brussels, I985).

I6. Muriel Neven, "Espaces ruraux et urbains au XIXe siècle: trois régimes démographiques belges au coeur de la révolution industrielle", Popolazione e storia, 2 (2002), pp. 35-62, 50. 17. Idem, Individus et familles: les dynamiques d'une société rurale. Le Pays de Herve dans la seconde moitié du XIXe siècle (Liège, 2003).

I 8. Machteld De Metsenaere, "Le choix du conjoint, indicateurs des changements linguistiques à Bruxelles au XIXe siècle”, in Brunet, Fauve-Chamoux, and Oris, Le choix du conjoint, pp. 77-92. 
our data do cover a wide range of contexts and histories while we aim precisely at showing the effects of context on the paths taken by societies, as far as openness in choice of partner is concerned.

\section{THEOR Y}

\section{Partner selection}

To explain the influence on partner selection of modernization, migration, and occupational identities, we present a simple framework to examine partner selection. We distinguish three general determinants: ${ }^{19}$ structural causes, preferences, and social control.

Partner selection is influenced by the supply of potential partners (structural causes). There are two important elements to this. First, social structure determines group sizes in the marriage market; that is, the number of potential partners who belong to a specific social category (for example, the number of farmers or skilled workers). Second, the supply of potential partners is in practice influenced by meeting opportunities between different "types" of partner. Potential partners belonging to a specific category (farmers, for instance) can sometimes more easily meet similar individuals (other farmers) instead of members of other groups (workers, for example), for instance, because of spatial segregation according to social position. ${ }^{2 \circ}$

Individual evaluation criteria (preferences) are applied to partner selection. There are three main principles of evaluation that inform the "development" of preference patterns in partner selection:

Rational-instrumental selection ("he or she is the most suitable choice"). This principle was highly valued in the contemporary literature. ${ }^{21}$ It may be applied to the social position of the father (social origin) or to the social position of the spouses, reflecting their personal "merit", in which case the level of intergenerational social mobility is an important cause of heterogamy according to social origin.

19. Marco van Leeuwen and Ineke Maas, "Huwelijksmobiliteit in Friesland tussen 1850 en 1929", It Beaken, 63 (200I), pp. 64-178; Frans van Poppel, Aart Liefbroer, Jeroen Vermunt, and Wilma Smeenk, "Love, Necessity and Opportunity: Changing Patterns of Marital Age Homogamy in the Netherlands, I850-1993", Population Studies, 55 (2001), pp. I-I3; Bart Van de Putte, "Het belang van de toegeschreven positie in een moderniserend wereld. Partnerkeuze in $19^{\mathrm{de}}$-eeuwse Vlaamse steden (Leuven, Aalst en Gent)" (Ph.D., Catholic University of Leuven, 2003).

20. On the role of spatial proximity, see Jacquemin, "Alliances et reproductions socials", PP. I2I-I 22.

21. Denis Bertholet, Le bourgeois dans tous ses états: le roman familial de la Belle Epoque (Paris, 1987); George Alter, Family and the Female Life Course: The Women of Verviers, Belgium, I849-I880 (Madison, WI, I988), pp. I45-I 47 . 
Romantic-expressive selection ("he or she is the only 'true' partner"). If this principle is applied, heterogamy according to social origin may be expected to increase, ${ }^{22}$ although the consequences of romantic love for heterogamy are sometimes questioned..$^{23}$

Selection based on "group belonging" ("he or she is an insider"). If this principle is applied, cultural values and prejudice against outsiders are important causes of homogamy (for example the identification of sons with the occupational group of their father, aversion to migrants). If, for example, social groups are defined by the occupation of one's father, one can expect the selection of a marriage partner to be restricted to this "ingroup". ${ }^{24}$

Partner selection is often controlled or at least influenced by the preferences of third parties (social control), whether parents, peers, priests, or perhaps colleagues: some argue, for example, that spouses, especially the young and the upper classes, married the "right" partner often because of social control. ${ }^{25}$

Underlying the idea of modernization and the increase in societal openness are the claims that, (I) rational-instrumental selection was applied increasingly to the social position of the spouses instead of to the social position of the father, which suggests a meritocratic element; or (2) that romantic-expressive selection increasingly replaced rational-instrumental selection; or, (3) that there was a de-identification with the occupation of the father; or, (4) that there was a weakening of traditional forms of social control. Of course, these causes are not mutually exclusive. The idea of demographic class-formation adds to this the notion that definitions of the identifiable social group did not simply disappear but

22. Marco van Leeuwen and Ineke Maas, "Partner Choice and Homogamy in Sweden in the Nineteenth Century: Was there a Sexual Revolution in Europe?", Journal of Social History, 36 (2002), pp. I0I-I 23; Edward Shorter, The Making of the Modern Family (New York, 1975), pp. I 57-I 59; Bart Van de Putte and Koen Matthijs, "Romantic Love and Marriage: A Study of Age Homogamy in Nineteenth-Century Leuven”, Belgisch Tijdschrift voor Nieureste Geschiedenis, 2 I (200I), pp. 579-61 9; Frans van Poppel, Aart Liefbroer, and Wendy Post, "Vers une plus grande homogamie d'âge entre conjoints: différences entre les classes sociales et différences régionales aux Pays-Bas, I8 I 2-I91 2", Annales de Démographie Historique, (1998), pp. 73-1 10, $75-76$.

23. Peter Borscheid, "Romantic Love or Material Interest: Choosing Partners in NineteenthCentury Germany", Journal of Family History, i I (1986), pp. I57-ı68; François Héran, "Finding a Spouse: A Survey of How French Couples Meet", Population: An English Selection, I (1989), pp. 9I-I 2 I.

24. William Sewell, "Social Mobility in a Nineteenth-Century European City: Some Findings and Implications", Journal of Interdisciplinary History, 7 (1976), pp. 225-230.

25. Steve Hochstadt, "Demography and Feminism", in P. Robertson (ed.), An Experience of Women: Pattern and Change in Nineteenth-Century Europe (Philadelphia, PA, I982), pp. 54I560,544 . 


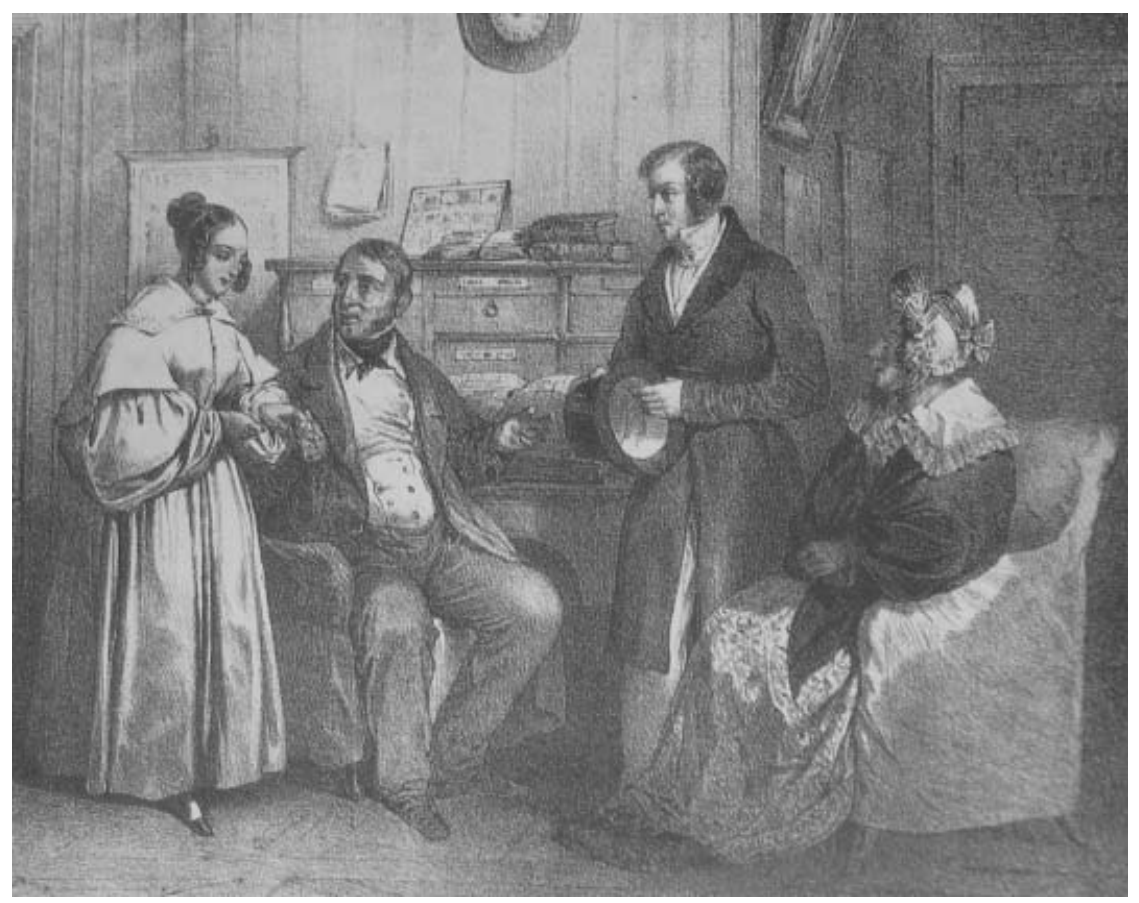

Figure 2. Parents exercised social control by accepting or refusing marriage candidates.

"L'album moral" d'aprés Jules David, $19^{e}$ siècle, from: E. Van Driessche (ed.), Des accordailles aux épousailles, Galerie CGER, Bruxelles, I9 février-I mai I988 (Brussels, 1988), p.3I. Used with permission.

became broader and included the whole lower class instead of just the one specific occupational group.

In the next sections we shall show how migration and occupational identity fit into this scheme and describe how those variables differ in the selected locations.

\section{The role of migration}

There are four reasons to associate migration with social heterogamy. First, migration can lead to a decline in social control. If parents are not present, that is to say if children and parents do not migrate together, marriage candidates may behave more freely. ${ }^{26}$ Not only might traditional preferences be less strongly "controlled" by the parents of those who, as a

26. Michel Oris and Emiko Ochiai, "Family Crisis in the Context of Different Family Systems: Frameworks and Evidence on When Dad Died", in Renzo Derosas and Michel Oris (eds), When Dad Died: Individuals and Families Coping with Distress in Past Societies (Berne [etc.], 2002), pp. $17-79,45-47$. 
result of this mobility ${ }^{27}$ before marriage, became, as it were, emancipated; we also see obvious cases in nineteenth-century Belgium where young men and women quite literally "escaped" from the parental control exercised in their strictly Malthusian villages. ${ }^{28}$

Second, migration can limit the use of the social network of parents. Even if parents are present, their ability to support their children in their selection of a partner might be limited because of their migration, in much the same way as the deaths of parents could have the same effect. ${ }^{29}$ Consequently, social origin is, in a sense, less useful when considered for migrants than for natives. If partner selection is based on rationalinstrumental selection by reference to the social position of parents, then following this logic we should expect migrants to be more likely to marry a partner of lower social origin.

Third, migration is frequently, although not systematically, linked with social mobility. The decision to migrate is often related to an individual's perception of the future within the community of origin. Since the Belgian countryside reached its demographic climax only in the late nineteenth century, without any real easing before I 890 of the Malthusian brake of late marriage and high rates of celibacy, ${ }^{30}$ we can say that those who could, stayed. ${ }^{3 \text { I }}$ Sons and daughters of farmers usually migrated to the city if the possibility of earning a living in their home village was limited. If the lower social position of a child who had migrated were to be taken into account, it would become difficult to marry a partner of the same social origin. But of course, migrants could avoid that pitfall by marrying other migrants.

Fourth, the presence of migrants and the desire to marry homogamously according to geographical origin can have consequences for partner selection according to social origin. If geographical origin is the main principle used in partner selection, and if there is a large migrant group available for marriage, it becomes more difficult to marry a partner of the same social origin. Indeed, if the number of potential partners is reduced to those of the same geographical origin, the chances of marrying somebody

27. Didier Blanchet and Denis Kessler, "La mobilité géographique, de la naissance au mariage", in Jacques Dupâquier and Denis Kessler (eds), La société française an XIXe siècle. Tradition, transition, transformations (Paris, 1992), pp. 343-377, 346.

28. Michel Oris, Catherine Capron, and Muriel Neven, "Le poids des réseaux familiaux dans les migrations en Belgique orientale au ige siècle. Peut-on quantifier?”, in Eugenio Sonnino (ed.), Living in the City (Rome, 2002), pp. I I I-I78.

29. Grazyna Ryczkowska, "Accès au mariage et structures de l'alliance à Genève, I800-I880", (M.A. thesis, University of Geneva, 2003), esp. pp. I06-1 I0, I21-123.

30. Bierbeek is an exception since the mean age at marriage declined earlier. See Koen Matthijs, De mateloze negentiende eeuw. Bevolking, huwelijk, gezin en sociale verandering (Leuven, 200I).

31. Muriel Neven, Individus et familles, ch. 9; Michel Oris, "The Age at Marriage of Migrants During the Industrial Revolution in the Region of Liège", The History of the Family: An International Quarterly, 5 (2000), pp. 391-4I3, 408-409. 
of the same social origin are automatically smaller. ${ }^{32}$ While the first three reasons imply that migrants are more heterogamous, this fourth reason implies a higher level of heterogamy more generally.

Table 3 overleaf shows the proportion of migrants among spouses in the Belgian cities and villages. The difference between grooms and brides is largely an artefact and can be explained by the custom of celebrating the marriage in the bride's locality. The table shows that in most locations the population of spouses had a large component of migrants. Given the relatively high levels for the villages, especially Pays de Herve and Appelterre, spatial mobility was not a characteristic unique to urban populations. As such, the large presence of migrants justifies this more thorough discussion of the role of migration in the process of partner selection. Furthermore, in Flanders natives tended to stay dominant, but in Wallonia they were a minority, except in the Ardennes. Clearly, in small industrial suburbs like Tilleur and Limbourg migration created new populations.

The migrant group was diverse. They were both rural and non-rural, foreigners and Belgians, Flemish and French-speaking. Particularly important, because of the spectacular growth there, was the presence in both Liège and Tilleur of the Flemish: in Liège from I 874- I 89026 per cent of grooms were either Flemish or foreign, while before i 850 only i 2 per cent had been so; in Tilleur the figures were 43. I per cent and 23.9 per cent respectively (this was less the case for native brides, with fewer Flemish brides compared with Flemish grooms).

Consequently, the native Liège and Tilleur brides were increasingly operating in a marriage market on which there were many potential marriage candidates speaking a different language. Obvious discrimination against the Flemish ${ }^{33}$ and endogamy among them have been observed in Liège and Tilleur. ${ }^{34}$ Furthermore, as, in Tilleur at least, these spouses did not come from the same or even adjacent villages, this endogamy of the

32. Van de Putte, "Het belang van de toegeschreven positie". The role of migration is probably somewhat different in the countryside. Most migrants are born rather close to the village of marriage and are not necessarily "special"; they did not come from far away nor did they "leave" their old social environment.

33. Yves Quairiaux and Jean Pirotte, "L'image du Flamand dans la tradition populaire wallonne depuis un siècle", Res publica. Revue de l'Institut belge de science politique, 20 (1978), pp. 39I406; Jacquemin, "Alliances et reproductions socials". For other studies of segregation according to geographical origin on the marriage market, see Van de Putte, "Het belang van de toegeschreven positie", on Flanders; Jacquemin, "Alliances et reproductions socials", on the Flemish in Liège; Leslie Page Moch, Moving Europeans: Migration in Western Europe since I650 (Bloomington, IN [etc.], I992), pp. I43-I47; Patricia van den Eeckhout and Peter Scholliers, "Social History in Belgium: Old Habits and New Perspectives", Tijdschrift voor Sociale Geschiedenis, 23 (1997), pp. I47-18 I, 160.

34. Anne Jacquemin, "Un éclairage de la sociabilité en milieu urbain à partir des actes de mariages liégeois (1840-1890)", Congrès de Liège des 20-23 octobre 1992 (Liège, I994), pp. 346360; Oris, "The Age at Marriage". 
Table 3. Percentage of spouses not born in the place of marriage

\begin{tabular}{lccccc}
\hline Location & \multicolumn{2}{c}{ Grooms } & & \multicolumn{2}{c}{ Brides } \\
\cline { 2 - 3 } \cline { 5 - 6 } & $\%$ & $\mathrm{~N}$ & & $\%$ & $\mathrm{~N}$ \\
\hline Aalst & 31.0 & 5,194 & & 24.8 & 5,171 \\
Leuven & 40.7 & 8,437 & & 36.7 & 8,623 \\
Ardennes & 41.7 & 1,690 & & 24.2 & 1,690 \\
Bierbeek & 42.2 & 2,118 & & 18.6 & 2,112 \\
Ghent & 43.2 & 8,565 & & 40.0 & 8,555 \\
Liège & 54.8 & 4,461 & & 51.4 & 4,461 \\
Appelterre & 57.4 & 1,173 & & 27.5 & 1,164 \\
Verviers & 58.6 & 2,176 & & 50.0 & 2,176 \\
Pays de Herve & 66.3 & 1,221 & & 40.8 & 1,221 \\
Limbourg & 75.3 & 1,183 & & 61.3 & 1,183 \\
Tilleur & 92.2 & 1,055 & & 77.3 & 1,055 \\
\hline
\end{tabular}

Flemish was not the result of the marriages of "almost married couples" marrying in the city of destination, but rather from rejection and marginality. It differs from endogamy among, for example, native weapon-makers in Liège - which was done from choice. A calculation of the association between the two variables "geographical origin of groom" and "geographical origin of bride" (using a variable with three categories: natives, foreigners, and Flemish, other migrants) shows that homogamy was strong (Cramers V is 0.43 for Liège and 0.64 for Tilleur, while much lower for the other cities, in which the value is maximally about 0.2).

\section{Occupational identity}

By "occupational identity" we mean the tendency of individuals to define their social identity in terms of their own occupation or that of their family. We refer specifically to a son's identification with the occupation of his father. Occupational identity was traditionally important as an organizing principle of social life, as a shaper of social contacts between persons and families with the same occupation. ${ }^{35}$ First, as observed by Sewell for nineteenth-century Marseilles, ${ }^{36}$ occupational identity stimulates intergenerational immobility, which will probably lead to more

35. See for example Scarlett Beauvalet-Boutouyrie, La démographie de l'époque moderne (Paris, 1999), p. I25; Miles, Social Mobility, p. I45; Kathlijn Pittomvils, "De Gentse maatschappijen van onderlinge bijstand in de eerste helft van de negentiende eeuw. Solidariteit, staking en/of segmentering?”, Belgisch Tijdschrift voor Nieuwste Geschiedenis, 25 (1994-1995), pp. 433-479. 36. Sewell, "Social Mobility in a Nineteenth-Century European City"; see also Miles, Social Mobility, ch. 4 . 
homogamy according to social origin. Second, occupational identity might have tended to stimulate homogamy because it contributed importantly to a sense of belonging to an occupational group. ${ }^{37}$

Industrialization, urbanization, and the rise of modern cities, with their greater opportunities for anonymous meeting and the availability of new occupations, challenged "traditional" occupational identities and occupational immobility down the generations, which can always result in a more open pattern of partner selection. Yet this "modernization" view needs to be qualified, because industrialization does not necessarily lead to the gradual decline of occupational identities. First, especially during the first stages of industrialization, large industrial sectors were created, the textile and mining industries being examples. Some of these modernized occupational groups, especially the miners, are well known to have developed a strong sense of identity and formed cohesive groups. ${ }^{3}$ So, industrialization might in some cases even reinforce the role of occupational identities and help them stimulate homogamy.

Second, although there are signs of decreased differences among the lower classes, due for example to proletarianization and de-skilling, ${ }^{39}$ the transformation of modern industrial and other workers into one large group of "the lower class" was by no means a smooth process. Even if a modern labour movement wanted to alter group boundaries, in some situations sector-based social life and identity remained strong for a long time; indeed, the organizational outlook of the labour movement was originally based on those segmentations. ${ }^{40}$ In other words, in modern times too, not only class but occupation as well shaped social life and bolstered social dignity.

Third, some "traditional" occupational groups kept intact their tight social network and probably their homogamous marriage pattern for a very long time. Most survived the first industrial revolution, which was limited to a few leading sectors, but progressively they were weakened by the diffusion of mechanization and industrial organization into craft sectors of production..$^{4 \mathrm{I}}$ The Liège weapon-makers are a good example of

37. Grazyna Ryczkowska and Gilbert Ritschard, "Mobilités sociales et spatiales. Parcours intergénérationnels d'après les mariages genevois, I830-I880", paper presented at the sth European Social Science History Conference (Berlin, 24-27 March 2004).

38. Diana Cooper-Richet, Le peuple de la nuit: mines et mineurs en France (XIX-XXe siècle) (Paris, 2002); Claude Gaier, Huit siècles de houillerie liégeoise: histoire des hommes et du charbon à Liège (Liège, 1988).

39. Neven, "Mortality Differential and the Peculiarities of Mortality in an Urban-Industrial Population”, pp. 297-329; Scholliers, De Gentse metaalbewerkers, p. 36.

40. In Verviers, as late as 1906 the Textile Workers Federation included The Federation of Combed Woolworkers, The Federation of Carded Woolworkers, The General Association of Weavers, The Wool Washers, and five others groups.

4I. Michel Oris, "Le contexte économique et social", in Histoire des Sciences en Belgique (Brussels, 2001), pp. 37-70, 4I. 
that. ${ }^{42}$ Also farmers usually have a strong occupational identity, which is reinforced by the importance of the rational-instrumental criterion in partner selection. ${ }^{43}$ For children of farmers who are themselves farmers, it is often important to marry a partner from a farming background, perhaps to pool property or just because farming skills are an attractive quality in a spouse. The higher level of social control in the countryside strengthens this narrow group life. ${ }^{44}$ Consequently, the differences in absolute homogamy between locations and their evolution over time are possibly strongly influenced by the size of the group of farmers. This is not as trivial as it might seem, since it was precisely those levels of absolute homogamy that were rather important to the daily experience of societal openness. ${ }^{45}$

To assess the strength of occupational identities in the cities and villages we calculated the percentage of grooms working in the same sector (HISCO, first two digits) as their fathers. We found, first, that there was no general and strong decline in occupational immobility, although in Aalst in the period after I 890 and in Liège and Tilleur after I 850 there was a modest decrease of about io per cent. Second, the level of intergenerational occupational immobility was surprisingly high for some occupations, not only in traditional but also in some new sectors. In Tilleur and Liège the percentage of sons who followed their fathers into mining was high, respectively 74.6 per cent and 62 .I per cent, while among the fathers miners accounted for respectively 70 per cent and 20 per cent of lowerskilled workers. Among the textile workers of Verviers and Limbourg intergenerational occupational immobility was the most frequent option too, especially in Limbourg ( 76.4 per cent compared with 54.5 per cent in Verviers, while among the fathers textile workers accounted for respectively 60 per cent and 72 per cent of the lower-skilled workers). In Flanders there were no occupations that showed such high levels of "immobility" and only textile workers showed a distinct pattern. In Ghent, where about 29 per cent of the lower-skilled were textile workers, the general level of intergenerational occupational immobility was about 30 per cent, while for textile workers it was one of the highest (at 40 per cent), which shows indeed that industrialization did not necessarily lead directly to strong occupational mobility, implying the absence of a potentially strong stimulus to heterogamy.

A particular case revealing the importance of occupational identity can

42. Claude Gaier, Quatre siècles d'armurerie liégeoise (Liège, 1976); René Leboutte, Reconversions de la main-d'oeuvre et transition démographique. Les bassins industriels en aval de Liège. XVIIe-XXe siècles (Paris, I988).

43. Martine Ségalen, Mari et femme dans la société paysanne (Paris, I980).

44. Muriel Neven and Michel Oris, "Contrôle religieux, contrôle social: la fécondité dans l'est de la Belgique dans la seconde moitié du XIXe siècle”, Annales de Démographie historique, 2 (2003), pp. $5-32$.

45. Van de Putte, "Het belang van de toegeschreven positie". 
be observed in Verviers. After I 873, Verviers' industry declined more steeply than elsewhere and was in fact the Walloon "pioneer" of industrial decline. Simultaneously there was an early process of class formation there. That resulted in many trade unions, federations, cooperatives, an affiliation to the Belgian Workers' Party in I885 and, although only later, in the I 890 s, widespread strikes. Verviers was thus a pioneer city in the labour movement, a city where a new sense of belonging emerged quite early and quickly, at least more so than in Liège or Tilleur. The combination of economic stagnation and early labour movement activity perhaps initially (say before i 890) stimulated occupational- and sector-based social life, just as traditional occupational organizations did. It is plausible to suggest that this strengthening of group bonds itself led to homogamy. This period of stagnation must be distinguished from the phase of urban crisis in the first half of the nineteenth century, conditions in which heterogamy was favoured. ${ }^{6}$ We assume that the restoration of occupational identity by early class formation is strongest for the rooted population. In many eighteenth- and nineteenth-century cities, such as Grenoble or Geneva, ${ }^{47}$ a distinction is made between the rooted population, seen as the "core" of the city, who own and proudly transmit its local civic culture, and the mobile population, who are just "passing through".

Ghent's history shows similarities: economic expansion was less strong after I 850 , and, although the number of textile enterprises and workers increased, their proportion within the whole economy declined..$^{8}$ The labour movement in Ghent too became important, especially after I 890 , but before then there were important associations, of spinners and weavers for example, which were organized on the basis of their occupation.

Finally, in the villages, high levels of occupational immobility were habitual among farmers. The highest level is observed in Appelterre (72.5 per cent), the lowest in Bierbeek ( 58.3 per cent), and there was great immobility (68 per cent) in the Ardennes and the Pays de Herve.

\section{Occupational identity, class, and migration}

Occupational identity, class, and migration were clearly related. Some occupational sectors, for example the textile industry in early nineteenthcentury Ghent or weapon-making in Liège, were preferred mainly by native city dwellers. Also, some "classes" were populated by specific groups.

\section{Ibid.}

47. For Grenoble, see Emmanuel Le Roy Ladurie, "La démographie des Lumières", in Histoire de la France urbaine, t. 3. La ville des temps modernes de la Renaissance aux Révolutions (Paris, 1998), pp. 293-347, 30I. For Geneva, see Ryczkowska and Ritschard, "Mobilités sociales et spatiales".

48. André Capiteyn, Johan Decavele, Christine Van Coile, and Herman Vanderlinden, Gentse torens achter rook van schoorstenen. Gent in de periode I860-I895 (Ghent, I983). 
The association between occupational structure, social structure, and migration adds complexity to the possible influence of those factors on partner selection. First, opportunities for meeting between partners of different social origin may be restricted if migrants have a specific social origin or if migrants are over-represented in specific groups or, for that matter, under-represented in others. For example, if migrants usually meet other migrants, and if most migrants are sons and daughters of farmers while the natives are not, that will stimulate homogamy among farmers, irrespective of the preferences those migrants and natives might have for any specific social origin. This principle is the so-called by-product effect, ${ }^{49}$ and occurs if two conditions are fulfilled: that there is a difference in the socio-economic profile of migrants in relation to natives, and that there is homogamy according to geographical origin.

Second, the mechanisms behind the isolation of migrants and natives and behind the isolation of specific occupational sectors (strong and narrow in-group definitions) may reinforce each other, which makes them potentially strong obstructors of societal openness, since they help produce strong senses of identity..$^{\circ 0} \mathrm{~A}$ language boundary, for example, might reinforce the formation of separate social networks.

Third, the association between social and geographical origin can alter social structure and so change group sizes. In our view, that is more important for the villages where, perhaps due to changing economic activities such as those brought about by the rise of rural industry, immigration of non-farmers could open the closed social systems of farming communities.

We briefly discuss here the socio-economic profile of migrants and natives in the Belgian cities and villages. In general, associations between geographical origin (natives/migrants) and social (HISCLASS) were not very strong. In most cities and villages Cramers $\mathrm{V}$ was about 0.2. Yet in Leuven, Cramers V was about 0.43 , in Ghent and Liège about 0.34 , and in Verviers 0.32 . The strength of the association fluctuated somewhat over time, but without a consistent trend. There is a lot to be said about specific associations, but to be concise we highlight only three. First in Flanders, French-speaking migrants with an urban background were disproportionately recruited to state institutions there, which led to overrepresentation of those migrants in the category of higher and lower managers and professionals. Second, in the Walloon textile cities, particularly in the recently developed town of Limbourg, natives and those born in the

49. Wilfred Uunk, Who Marries Whom? The Role of Social Origin, Education and High Culture in Mate Selection of Industrial Societies During the Twentieth Century (Nijmegen, 1996).

50. Jan Dhondt, "La région gantoise. L'industrie cotonnière", in Pierre Lebrun, Marinette Bruwier, Jan Dhondt, and George Hansotte (eds), Essai sur la révolution industrielle en Belgique, I770-I847 (Brussels, 1979), pp. 75-160; Claude Gaier, Huit siècles de houillerie liégeoise (Liège, 1988). 
neighbouring countryside dominated among lower-skilled workers, while urban migrants and foreigners were concentrated in skilled and leading positions. Third, in Tilleur 69 per cent of foreign grooms were lowerskilled workers, most of them coal miners, while 64 per cent of Flemish grooms were unskilled. But all this is just because foreigners arrived first, at the very beginning of the industrial revolution, before the rapid rise of the unskilled Flemish day labourer. ${ }^{5 \mathrm{I}}$

In the villages the socio-economic profile of migrants was to some extent different from that of the natives. In Bierbeek ( 80 per cent as against 66 per cent) and the Ardennes ( 80 per cent as against 52 per cent) there were more sons of farmers among the natives than among migrants. It is clear that, particularly in the Ardennes, migration altered social structure and therefore had consequences for marriage patterns. The pattern was different in the Pays de Herve migration, as farmers were more numerous among migrants there ( 55 per cent as against 40 per cent among natives). Among the natives there were more sons of skilled workers and farm workers. In Appelterre there was not much difference between the natives and migrants.

In the Ardennes this difference might have led to a by-product effect, since in the Ardennes there was a degree of homogamy according to geographical origin. Consequently, those who were homogamous according to geographical origin had a greater chance of marrying homogamously according to social origin. In a comparison between migrants and farmers, the difference in the percentage of farmers decreased from 33 per cent before i 850 to 17.5 per cent from I $874-1890$. We can see that the by-product effect would therefore decline over time.

\section{Conclusion}

In an attempt to introduce the influence of historical context formally into the debate about the increase of societal openness during the nineteenth century, we have identified possible patterns in which migration and occupational identities may be linked to partner selection by social origin. Table 4 gives an overview. In a short description of the historical context of these Belgian cities and villages we evaluated the importance of these factors. Apart from the general importance of migration, occupational identity, and, to some extent, the association between geographical origin and class, we saw that in some locations those factors created a specific societal context. We refer to the peculiar position of Flemish and

5I. Michel Oris, "Une démographie des familles dans le tourbillon de la révolution industrielle", in Anne-Lise Head-Hönig, Luigi Lorenzetti, and Béatrice Veyrassat (eds), Famille, parenté et réseaux en Occident (XVIIe-XXe siècles). Mélanges offerts à Alfred Perrenoud (Geneva, 200I), pp. $37-52$. 
Table 4. Overview of determinants of heterogamy

\begin{tabular}{|c|c|c|}
\hline Determinant & Specific reason & $\begin{array}{l}\text { Partner selection } \\
\text { by social origin }\end{array}$ \\
\hline \multirow[t]{4}{*}{ Migration } & Social control & Heterogamy \\
\hline & Lack of network, support & Heterogamy \\
\hline & Social mobility & Heterogamy \\
\hline & Wish to avoid migrants & Heterogamy \\
\hline \multirow[t]{3}{*}{ Occupational identity } & $\begin{array}{l}\text { Industrial occupational } \\
\text { identities }\end{array}$ & Homogamy \\
\hline & Early labour movement & Homogamy \\
\hline & $\begin{array}{l}\text { Persistency of traditional } \\
\text { identities }\end{array}$ & Homogamy \\
\hline \multirow{3}{*}{$\begin{array}{l}\text { Occupational } \\
\text { identification, class and } \\
\text { migration }\end{array}$} & Social structure & $?$ \\
\hline & Meeting opportunities & Homogamy \\
\hline & $\begin{array}{l}\text { Reinforced closed social } \\
\text { groups }\end{array}$ & Homogamy \\
\hline
\end{tabular}

foreigners in Liège and Tilleur after I850, the economic stagnation and early class-formation seen in Verviers, and the variety of rural economic and social contexts. Next, we shall try to establish whether migration and occupational identity were related to partner selection and if they determined a trend in this selection.

\section{METHODOLOGY}

In this section we give an overview of the models and variables used in our empirical analysis of partner selection by social origin. We use a series of models to analyse partner selection stepwise. In a first step we measure the basic trend in absolute heterogamy in each location. This first step aims to outline the general pattern of partner selection. In a second step we use logistic regression analyses ${ }^{52}$ to compare the levels of heterogamy between locations and over time. The outcome variable is "marrying heterogamously" versus "marrying homogamously". For categorical variables, the coefficients of the logistic regression analysis show the factor by which the odds of marrying heterogamously are higher (if the parameter is higher than I) or lower (if the parameter is lower than I) depending upon whether one belongs to a specific category of variable compared with the reference category of that variable. For non-categorical variables, the coefficients

52. We chose to use logistic regression analysis rather than log-linear analysis because the latter is difficult to use if there are many cells with zero or low frequencies in the mobility (or partner selection) table. This problem is particularly acute when adding many variables (with many categories) to the analysis. The advantage of log-linear analysis is the neat control of the effect of group sizes. We cope with this problem by introducing a group size variable in the logistic regression analysis; Van de Putte, "Het belang van de toegeschreven positie". 
refer to the difference in odds when there is a one point change in the independent variable. 53 The models will help us to see if group sizes, occupational identity, and migration are connected to partner selection patterns, and whether the pattern of homogamy is explained by this connection.

In model 1A we use period, location, and group size as the independent variables. Periods have been defined to reflect broadly the main structural socio-economic transformations: the first industrial revolution before I 850 , an ascending phase from i 85 I to I 873 , the long depression in both industry and agriculture from I874 to I890, and a new ascending Kondratieff from I89I to I9I3. The group size variable controls for the influence of changing social structure on the chance of marrying heterogamously. We look at things from the perspective of the groom. For each category of social origin, we calculate the percentage of brides' fathers belonging to that same category. The percentage shows the chance of marrying homogamously. 54

We also add an interaction variable between period and location. In a model containing interaction effects, the main effects of the variables included in the interaction effect (here: period and location) show the effects within the reference group of the other variable in the interaction effect. For example, the parameters for location show the difference in the chance of marrying heterogamously between the locations in the reference period. The period effect shows the coefficients for the reference location. The interaction effects of location and period show how that period effect differs in the other locations: the parameter of the interaction effect for a specific location by a specific period shows the factor by which the main effect of this period must be multiplied to become the period effect for the specific location.

In model $2 \mathrm{~A}$ we add variables for migration, occupational identity, geographical homogamy, and presence of parents. The migration status of groom and bride is measured by the type of area where they were born. We distinguish among natives, Flemish (or "Walloon" in Walloon locations) rural migrants, Flemish (Walloon) non-rural migrants, foreigners, unknown, and Walloon (Flemish) migrants. Occupational immobility is measured as $\mathrm{I}=$ groom has the same occupation as father (reference), while $2=$ groom does not have the same occupation as father. We assume

53. In technical terms, the parameters are odds ratios (of the odds of marrying heterogamously for a category of the independent variable divided by the odds of marrying heterogamously for the reference category).

54. The introduction of this group size variable controls for the distribution of the social origin of both brides and grooms. If the distribution of the social origin of the grooms changes, that leads to changing numbers of grooms assigned to specific group size values. If we take the perspective of the bride, the same results appear. We take the perspective of the groom simply to demonstrate the logic of controlling for group sizes, as a didactic trick. 
that occupational identity is strongest in the reference category. Geographical homogamy is simply measured as: $\mathrm{I}=$ marriage is homogamous according to geographical origin (reference); 2 = marriage is heterogamous according to geographical origin. We use the migration status of groom and bride to measure this dimension of homogamy. If there is an association between social origin and geographical origin (by-product), then geographically homogamous marriages will tend to be more homogamous according to social origin. Parental presence is measured as: $\mathrm{I}=$ father lives in the city of marriage; $2=$ father does not live in the city of marriage; and $3=$ no information. This variable is only available for the Flemish locations.

In model $3 \mathrm{~A}$ we add the social origin of the groom. This model tests whether the evolution of homogamy is caused by change of social structure. If groups who are traditionally more homogamous (farmers, the elite, for example) decrease in number, that will affect the level of homogamy. Social origin is measured using HISCLASS.

We perform separate analyses for cities and villages, because, as will be shown in Table 5, p. 202, the pattern of partner selection is so different in them that direct comparison would lead us to focus on merely trivial differences, and would anyway require the introduction of an incomprehensible number of interaction effects. Furthermore, analysing the role of farmers requires a somewhat different approach. So to analyse the second step in the villages we used slightly different models. First, we dropped the interaction variables between period and location so as to avoid numerous interaction effects $(1 \mathrm{~B}, 2 \mathrm{~B}$, and $3 \mathrm{~B})$. While for cities there are specific contextual characteristics in each period which can be interpreted, and which allow useful comparisons over time between cities, that is not true, or is less so, for villages. Second, to assess the effect of the evolution of the farmers' group size, models $1 \mathrm{~B}$ and $2 \mathrm{~B}$ are compared with models $1 \mathrm{C}$ and $2 \mathrm{C}$, which exclude the group size variable, the reason for which is that the partner selection pattern is strongly related to the number of farmers. Finally, to avoid categories with very few observations we replaced "social origin" ("farmers" and "non-farmers") and "geographical origin" ("natives" as opposed to "migrants") by a dichotomous variable.

The models of step 2 naively assume that these factors produce the same results in every location and at all times. More detailed examination is needed to evaluate whether there are interaction effects of these variables with period and location. In step 3 we therefore examine the results obtained in steps I and 2 by connecting them with their historical contexts, for example with the position of the Flemish in Liège and Tilleur and with the process of early class formation in Verviers. For the cities we make some additional comparisons (heterogamy by migration status and by geographical homogamy). For the villages we applied the models $1 \mathrm{~B}, 1 \mathrm{C}$, $2 \mathrm{~B}$, and $3 \mathrm{~B}$ to each location separately. 


\section{A MULTIVARIATE ANALYSIS OF HETEROGAMY}

\section{Partner selection in the cities}

We start with the analysis of the general trend in absolute heterogamy in the cities (step I, Table 5). The main and, seen from a modernization perspective, rather puzzling finding is the difference in the evolution of heterogamy before 1890 . In the first half of the nineteenth century, the highest levels of heterogamy found are for Ghent, Liège and Verviers, the lowest for Aalst. In the period I 874-I890 the situation changed. The level of heterogamy in Verviers became lower than for other industrial cities. The reason for that is the moderate increase in heterogamy in particular for Liègess and the decrease in heterogamy in Verviers. ${ }^{56}$ If we consider the situation in the period I 89I-I9I 3 we observe that, due to a strong rise in heterogamy after I 890 , the level of heterogamy in Aalst was by then comparable to the level in Ghent and Leuven, cities in which heterogamy did not increase.

To understand how those patterns emerged we examine these observations in more detail. First, we discuss the pattern before 1890 , focusing on the different situations in Liège and Verviers. Second, we address the increase in heterogamy in Aalst after I 890.

Heterogamy before I890: First we test whether the differences in heterogamy are related to the direct influence of changing group sizes, occupational immobility, and migration (step 2 ). Table 6 shows the evolution of heterogamy using the logistic regression models $1 \mathrm{~A}, 2 \mathrm{~A}$, and $3 \mathrm{~A}$.

The results of model IA confirm the diverging patterns in the level of homogamy in those cities. In the reference period I 874- I 890 heterogamy is highest for Liège, as all coefficients of the other cities are lower than I. In Leuven, Aalst, and Verviers the level of heterogamy is significantly lower. The period effects show that in Liège heterogamy was lower before the period I 874-I890.57 For Verviers, these period effects are very different. There was no similar increase. If we were to recode "location" with Verviers as the reference category, the parameters for period (referring now to Verviers) would show a higher, and significant, level of heterogamy during the periods I $800-1850$ and I 85 I-I 873 than during I $874-1890$. The

55. The increase in heterogamy in Tilleur and Limbourg is not significant. The social structure changed over time. The number of lower-skilled workers among Limbourg fathers (of both brides and grooms) declined after I 873 , as did the number of farmers (but only of grooms); the number of unskilled workers rose, although only among fathers of brides. Such changes in Limbourg's social structures are not easy to interpret. They are essentially artificial and due to territorial changes in the early i 880 os.

56. Note that though these changes might not be very large, the contrasting trends between Liège and Verviers are striking.

57. The borderline significance is partly related to the rather low number of observations for the first periods. If we use Liège as the reference category, and Tilleur (which is in fact part of Liège and shares similar characteristics, such as the large number of Flemish and foreign migrants), then the period effects are significant ( 0.637 for period I and 0.658 for period 2). 


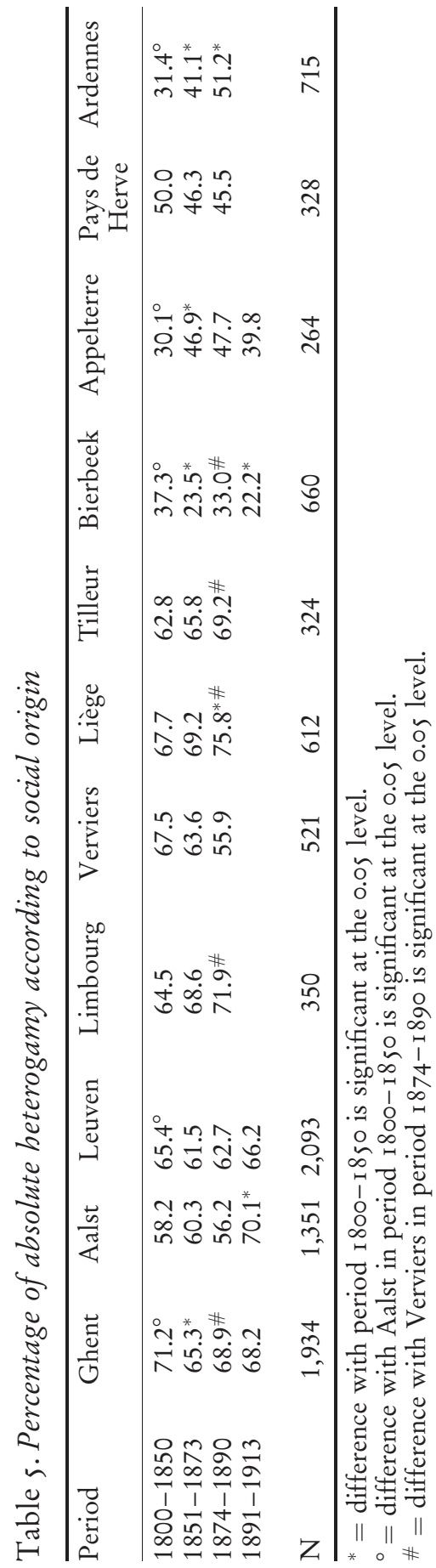


Table 6. Logistic regression analysis of the chance of marrying beterogamously according to social origin (Flemish and Walloon cities, I800I890)

\begin{tabular}{|c|c|c|c|c|c|c|}
\hline \multirow[t]{2}{*}{ Variables } & \multicolumn{2}{|c|}{ Model 1A } & \multicolumn{2}{|c|}{ Model 2A } & \multicolumn{2}{|c|}{ Model 3A } \\
\hline & Sig. & $\operatorname{Exp}(B)$ & Sig. & $\operatorname{Exp}(B)$ & Sig. & $\operatorname{Exp}(B)$ \\
\hline \multicolumn{7}{|l|}{ Period } \\
\hline $1800-1850$ & 0.104 & 0.651 & 0.060 & 0.604 & 0.071 & 0.615 \\
\hline $1851-1873$ & 0.057 & 0.682 & 0.030 & 0.642 & 0.031 & 0.642 \\
\hline \multicolumn{7}{|l|}{$1874-1890$ (ref.) } \\
\hline \multicolumn{7}{|l|}{ Location } \\
\hline Leuven & 0.002 & 0.568 & 0.000 & 0.502 & 0.000 & 0.505 \\
\hline Ghent & 0.132 & 0.748 & 0.048 & 0.678 & 0.060 & 0.689 \\
\hline Aalst & 0.001 & 0.531 & 0.000 & 0.465 & 0.019 & 0.612 \\
\hline Limbourg & 0.229 & 0.713 & 0.120 & 0.636 & 0.126 & 0.638 \\
\hline Verviers & 0.015 & 0.585 & 0.003 & 0.514 & 0.006 & 0.539 \\
\hline Tilleur & 0.363 & 0.751 & 0.633 & 0.869 & 0.726 & 0.889 \\
\hline $\begin{array}{l}\text { Liège (ref.) } \\
\text { Group size }\end{array}$ & 0.000 & 0.964 & 0.000 & 0.965 & 0.000 & 0.949 \\
\hline \multicolumn{7}{|l|}{ Location $*$ Period } \\
\hline Leuven by $1800-1850$ & 0.058 & 1.763 & 0.028 & 1.943 & 0.021 & 2.020 \\
\hline Leuven by $1851-1873$ & 0.161 & 1.427 & 0.095 & 1.536 & 0.087 & 1.554 \\
\hline Ghent by $1800-1850$ & 0.088 & 1.691 & 0.046 & 1.866 & 0.060 & 1.805 \\
\hline Ghent by $1851-1873$ & 0.443 & 1.220 & 0.276 & 1.331 & 0.274 & 1.335 \\
\hline Aalst by $1800-1850$ & 0.393 & 1.317 & 0.185 & 1.541 & 0.451 & 1.285 \\
\hline Aalst by $1851-1873$ & 0.130 & 1.510 & 0.065 & 1.668 & 0.181 & 1.463 \\
\hline Limbourg by $1800-1850$ & 0.465 & 1.343 & 0.350 & 1.468 & 0.263 & 1.591 \\
\hline Limbourg by $1851-1873$ & 0.277 & 1.481 & 0.298 & 1.463 & 0.266 & 1.510 \\
\hline Verviers by $1800-1850$ & 0.007 & 3.588 & 0.008 & 3.563 & 0.004 & 4.158 \\
\hline Verviers by $1851-1873$ & 0.007 & 2.157 & 0.004 & 2.282 & 0.002 & 2.418 \\
\hline Tilleur by $1800-1850$ & 0.721 & 1.168 & 0.784 & 1.128 & 0.962 & 1.022 \\
\hline Tilleur by $1851-1873$ & 0.582 & 1.236 & 0.541 & 1.272 & 0.666 & 1.192 \\
\hline Occupational mobility & & & 0.000 & 1.502 & 0.000 & 1.544 \\
\hline \multicolumn{7}{|c|}{ Occupational immobility (ref.) } \\
\hline \multicolumn{7}{|c|}{ Migrant status groom } \\
\hline \multicolumn{7}{|l|}{ Native (ref.) } \\
\hline Rural migrant & & & 0.017 & 0.791 & 0.234 & 0.884 \\
\hline Non-rural migrant & & & 0.002 & 0.724 & 0.014 & 0.774 \\
\hline Foreigner & & & 0.000 & 0.528 & 0.003 & 0.586 \\
\hline Unknown & & & 0.332 & 0.830 & 0.443 & 0.861 \\
\hline Walloon migrant & & & 0.000 & 0.565 & 0.002 & 0.636 \\
\hline \multicolumn{7}{|l|}{ Migrant status bride } \\
\hline \multicolumn{7}{|l|}{ Native (ref.) } \\
\hline Rural migrant & & & 0.221 & 1.124 & 0.161 & 1.147 \\
\hline Non-rural migrant & & & 0.512 & 0.933 & 0.596 & 0.945 \\
\hline Foreigner & & & 0.039 & 1.525 & 0.066 & 1.462 \\
\hline Unknown & & & 0.876 & 1.030 & 0.997 & 1.001 \\
\hline Walloon migrant & & & 0.197 & 0.807 & 0.269 & 0.831 \\
\hline $\begin{array}{l}\text { Geographically } \\
\text { heterogamous }\end{array}$ & & & 0.000 & 1.383 & 0.000 & 1.376 \\
\hline
\end{tabular}

(Continued overleaf) 
Table 6. Continued

\begin{tabular}{|c|c|c|c|c|c|c|}
\hline \multirow[t]{2}{*}{ Variables } & \multicolumn{2}{|c|}{ Model 1A } & \multicolumn{2}{|c|}{ Model 2A } & \multicolumn{2}{|c|}{ Model 3A } \\
\hline & Sig. & $\operatorname{Exp}(B)$ & Sig. & $\operatorname{Exp}(B)$ & Sig. & $\operatorname{Exp}(B)$ \\
\hline \multicolumn{7}{|l|}{$\begin{array}{l}\text { Geographically } \\
\text { homogamous (ref.) }\end{array}$} \\
\hline \multicolumn{7}{|c|}{ Social origin } \\
\hline Higher managers and prof & essiona & $(1+2)$ & & & 0.000 & 0.484 \\
\hline Lower managers and profe & essional & clerical a & ad sales & $(3+4+5)$ & 0.964 & 1.006 \\
\hline Skilled workers $(6+7)$ & & & & & 0.000 & 1.715 \\
\hline Farmers (8) & & & & & 0.005 & 0.708 \\
\hline Lower-skilled workers (9) & & & & & 0.001 & 1.461 \\
\hline $\begin{array}{l}\text { Farm workers }(10+12) \\
\text { Unskilled (11) (ref) }\end{array}$ & & & & & 0.145 & 1.355 \\
\hline Constant & 0.000 & 6.052 & 0.000 & 4.949 & 0.000 & 5.536 \\
\hline
\end{tabular}

Model information.

Model I A: $\mathrm{N}=4983$; model fit: $\mathrm{chi}^{2}=2 \mathrm{I} 2.4 ; \mathrm{p}=0.000$; Nagelkerke $\mathrm{R}^{2}=0.058$. Model 2A: $\mathrm{N}=4983$; model fit: $\mathrm{chi}^{2}=294.3 ; \mathrm{p}=0.000$; Nagelkerke $\mathrm{R}^{2}=0.080$. Model $3 \mathrm{~A}: \mathrm{N}=4983$; model fit: $\mathrm{chi}^{2}=400.9 ; \mathrm{p}=0.000$; Nagelkerke $\mathrm{R}^{2}=0.107$.

interaction effects of Verviers by "period" do indeed make clear that there was an evolution there of opposite character to that in Liège. The period effects for Tilleur and Limbourg differ less and not significantly. Finally, the parameter for group size indicates that the larger the number of equals among fathers of brides, the less the chance of a heterogamous marriage, which is of course not surprising.

The results of model $2 \mathrm{~A}$ show that occupational mobility and geographical heterogamy increase the chances of marrying heterogamously according to social origin. The latter shows that there is possibly a by-product effect, although the effect might also mean that preferences for homogamy according to social and geographical origin simply happen to coincide. The findings on geographical heterogamy and occupational mobility confirm the role of those factors in partner selection. These relationships are consistent, that is, present in each location (data not shown), which shows that in analysing partner selection according to social origin these variables should be taken into account. The role of migration is less clear. Migrant grooms have less chance of marrying heterogamously, but that is not so for migrant brides. On the contrary, even foreign brides have more chance of marrying heterogamously. That might signify that the role of migration is more complex than was envisaged in the theoretical section. For example, there might be interaction of migration by location, period, class, etc., or, perhaps, migrants might have had less chance than natives of experiencing upward mobility.

However, adding these variables does not mean that the differences 
between Liège (and Tilleur) and the other cities are explained by them. On the contrary, the main effects of location in model 2A show that the general level of heterogamy was still highest in Liège. The effect is significant for Verviers, Ghent, Leuven, and Aalst. In Tilleur the level of heterogamy is not significantly different. This means that, according to model 2A, in the period I874-1890 the level of heterogamy in Liège (and Tilleur) was higher than in the other cities but was not caused by, for example, a different level of occupational immobility.

In model $3 \mathrm{~A}$ social origin of the groom is added. Farmers and higher managers or professionals are shown to have been less heterogamous than unskilled workers. Skilled and lower-skilled workers were more heterogamous, and farm workers, who are rather unskilled, and lower managers and professionals do not differ in terms of heterogamy. Adding this variable to the model does not change the above observation.

In step 3 we connect these observations with the location-specific findings discussed earlier. First we return to the presence of the Flemish in Liège and Tilleur. We recall that in their situation priority was perhaps given to homogamy by geographical origin, which avoids having a partner who speaks a different language, and that in some cases it may be supposed that the principle of marrying a partner of the same social origin cannot be applied. The presence of Flemish and foreign migrants made it increasingly difficult to marry homogamously according to social origin if one wished to marry homogamously according to geographical origin.

This explanation is confirmed in Tables 7 and 8 for Liège, where we observe that native brides married more heterogamously according to social origin, since brides faced great difficulty in finding native partners, and that couples homogamous according to geographical origin were increasingly less homogamous by social origin, as a result of the increasing difficulty of combining both those criteria. In fact, the increase in heterogamy was limited to those groups. The increase in heterogamy for couples who were homogamous according to geographical origin is observed likewise for Tilleur. ${ }^{5}$ The same pattern did not appear for Verviers, Ghent, and Limbourg. The very fact that the increase in heterogamy so closely tallied with the composition of couples according to their geographical origin shows that more was taking place than simple modernization. In our opinion, the arrival of foreigners and Flemish people made it difficult especially for native brides to find native partners of the same social origin. This form of heterogamy was an indirect product of industrialization - since the rise of migration was itself the product of

58. For Tilleur the conclusions are more difficult, because of the low number of observations and the more complicated situation due to the extremely large number of migrants. We assume that the main schism lay between Walloon natives and migrants on the one hand and foreigners and Flemish migrants on the other. 
Table 7. Percentage of heterogamy according to social origin, by migration status of bride, Walloon cities and Ghent

\begin{tabular}{|c|c|c|c|c|c|}
\hline Period & Ghent & Limbourg & Verviers & Liège & Tilleur \\
\hline \multicolumn{6}{|l|}{ Natives } \\
\hline $1800-1850$ & 70.7 & 58.5 & 66.7 & 63.6 & 64.3 \\
\hline $1851-1873$ & 65.1 & 68.5 & 59.1 & 66.7 & 62.1 \\
\hline $1874-1890$ & 67.0 & 74.1 & $48.5^{*}$ & $79.4^{*}$ & 67.9 \\
\hline Total & 68.1 & 65.7 & 56.1 & 71.1 & 64.6 \\
\hline $\mathrm{N}$ & 827 & 134 & 243 & 325 & 99 \\
\hline \multicolumn{6}{|l|}{ Migrants } \\
\hline $1800-1850$ & 73.2 & 69.1 & 69.2 & 72.7 & 62.0 \\
\hline $1851-1873$ & 66.0 & 68.6 & 68.2 & 72.1 & 66.7 \\
\hline $1874-1890$ & 72.6 & 71.0 & 64.6 & 71.9 & 70.3 \\
\hline Total & 70.7 & 69.4 & 67.1 & 72.1 & 65.8 \\
\hline $\mathrm{N}$ & 314 & 216 & 278 & 287 & 225 \\
\hline
\end{tabular}

Table 8. Percentage of heterogamy according to social origin, by homogamy according to geographical homogamy, Walloon cities and Ghent

\begin{tabular}{lccccc}
\hline Period & Ghent & Limbourg & Verviers & Liège & Tilleur \\
\hline Homogamous & & & & & \\
1800-1850 & 68.8 & 64.3 & 56.3 & 61.8 & 48.8 \\
1851-1873 & 63.8 & 62.2 & 52.6 & 66.7 & 60.7 \\
1874-1890 & 67.5 & 65.4 & 49.3 & $78.6^{*}$ & $65.0^{*}$ \\
Total & 67.3 & 63.9 & 51.8 & 70.4 & 57.1 \\
N & 1,131 & 119 & 197 & 304 & 119 \\
\hline Heterogamous & & & & & \\
1800-1850 & 75.5 & 64.9 & 75.0 & 75.0 & 71.4 \\
1851-1873 & 67.3 & 70.9 & 70.2 & 71.6 & 68.9 \\
1874-1890 & 70.8 & 74.6 & $59.8^{*}$ & 73.2 & 71.1 \\
Total & 70.2 & 70.1 & 67.0 & 72.7 & 70.2 \\
N & 803 & 239 & 324 & 308 & 205 \\
\hline
\end{tabular}

$*=$ difference between period I800-I850 and period I $874-$ I 890 significant at the o.o5 level.

industrialization - but we are rather a long way from claiming that it was meritocracy that caused societal openness.

Second we turn to Verviers. In the theoretical section we argued that in some cases industrialization might have reinforced the role of occupational identity and so stimulated homogamy because, for instance, during industrialization large, modern industrial sectors were created with strong group bonds and because the organizational outlook of the labour movement was based upon occupational segmentations. The timing of the 
effect (contrast between urban crisis and a period of stagnation) and the location (not evident in either Limbourg nor Aalst; a similar but perhaps less marked pattern in Ghent ${ }^{59}$ ) suggest that this was indeed the case in Verviers.

Another indication may be found in the behaviour of the rooted population. In Table 8 we see that in Verviers couples who were homogamous according to geographical origin showed some lessening of heterogamy according to social origin. Distinguishing between native and migrant homogamous couples, we see that there was no decrease in heterogamy according to social origin for migrant homogamous couples, the least rooted couples (from 70 per cent before I874, to 69. I per cent thereafter). All other combinations do show a decrease, of at least 7 per cent, but the largest decrease (I 6 per cent) is for couples of whom the bride was native but the groom migrant. At first sight, this seems strange, as we can assume that natives who married endogamously were more rooted and so can be expected to show the greatest decrease in heterogamy. Yet the mixed nature of these marriages is itself perhaps proof of the integration of the migrants involved. Alter has shown that, among migrants, marrying a native bride was seen as a good strategy for stabilization and integration in the city. Much more so than elsewhere, a male migrant marrying a native bride in Verviers was a man who wanted to move from the mobile to the rooted group and his very marriage was inherently a success as well as a promise of further integration into the group of real Verviétois. ${ }^{60}$

Heterogamy after I 890: The next issue concerns the increasing level of heterogamy in Aalst after I 890. The timing of the effect is not surprising since Aalst experienced industrialization only late in the nineteenth century. At the same time it is important to note that although economic changes in Aalst were dramatic, they did not produce the same kind of changes of migration status in the composition of the population as occurred in the Walloon cities, and that after I 890 the majority of spouses were born in Aalst (75.2 per cent of brides and 69 per cent of grooms), percentages which are perhaps even slightly higher in comparison to earlier periods. A distinctive factor, however, is that Aalst industrialized in a period during which the labour movement attained its full strength, so the circumstances in which partners were selected were different from those in cities which industrialized earlier.

Table 9 shows the results of model $1 \mathrm{~A} .{ }^{6 \mathrm{I}}$ The parameters for location

59. Van de Putte, "Het belang van de toegeschreven positie". This observation for Ghent was made using a different class scheme (SOCPO scheme). In the period I800-1850 the level of heterogamy was 6 per cent higher than in the period I 85 I-I 890 , but Io per cent higher if the observation is limited to the lower classes, for whom the strongest effects are expected. Using HISCLASS, which differs in some ways from SOCPO, this decrease is less sharp.

60. Alter, Family and the Female Life Course.

6r. We limit the analysis to the Flemish cities, as it is only for these cities that we have observations for the period I89I-I9I3. 
show the difference in the chance of marrying heterogamously between locations in the reference period I89I-I9I3. The level of heterogamy in Ghent and Leuven did not differ significantly in I89I-I9I 3 from the level of heterogamy in Aalst. The parameters for period show the period effects for the reference location, Aalst. It is clear that in Aalst heterogamy was highest in the period I89I-I9I3. The interaction effects for period and location signify that in the periods I $800-$ I 850 and I $874-$ I 890 heterogamy was significantly higher in Leuven and Ghent than it was in Aalst.

In model $2 \mathrm{~A}$ migration status of groom and bride, homogamy by geographical origin, occupational identity, and parental presence are added. Geographical heterogamy and occupational mobility have a positive effect on heterogamy. Grooms whose father was present in the city of marriage had a greater chance of marrying heterogamously. ${ }^{62}$ It is also clear that migration in general did not have major effects on heterogamy. In this analysis the period effects for Aalst are still present after controlling for those factors, which shows that while occupational mobility and geographical heterogamy are important, they do not in themselves constitute the explanation for the increase in heterogamy in Aalst.

In model 3A we add "social origin groom" to the previous model. The difference between I89I-I9I3 and the other periods disappears after controlling for this variable, apart from the difference in the period i $800-$ I 850 . This is probably related to the increased number of lower-skilled textile workers as a result of industrialization in Aalst and, from I89II9 3 , the decreasing number of unskilled workers and farmers, two groups which differ in their "traditional" level of heterogamy. Before i 890 the lower skilled too were a heterogamous group while the unskilled and farmers were more homogamous.

To sum up, the increase in heterogamy in Aalst was not caused by changes in migration nor occupational identity. That does not necessarily mean that meritocracy alone was on the rise. Van de Putte found that heterogamy after 1890 in Aalst, as in Ghent, ${ }^{63}$ was for the most part

62. It is difficult to explain this, but we must add here that heterogamy might also mean upward mobility, and one cannot exclude the notion of the father as a tool for upward mobility rather than as a "keeper of homogamy".

63. It took some time for the labour movement to become a nationwide mass movement. In our opinion, it was only after 1890 that the broader process of demographic class formation started, understood as the process by which boundaries among the lower classes disappeared while the boundary between the middle class and the lower classes remained. This period is not under observation for Verviers, so we cannot consider whether heterogamy among the lower classes increased after that date. Van de Putte ("Het belang van de toegeschreven positie") observed this pattern of demographic class-formation for the industrial cities of Aalst and Ghent after I 890. Using a different class scheme (SOCPO scheme) an increase was observed in heterogamy for both Ghent and Aalst. The different results for Ghent are mainly the result of the use of some sector-based social classes by HISCLASS (SOCPO does not use sector as a criterion). The effect 
heterogamy within the lower classes, so it indicated a process of demographic class formation. In other words, apart from possible changes in the meritocratic outlook of society, changes in group belonging were probably important: one saw, in effect, the rise of a broad lower-class group. Moreover, nor can one rule out the possibility that in the case of Aalst there was more than simply modernization or demographic class formation, for while the Belgian socialist labour movement became a mass movement during I 890-I9I 3 the Catholic labour movement also emerged and became a formidable opponent. In that period, workers were divided ("pillarization") by these competing ideologies. In Aalst the Catholic labour movement was especially strong ("Daensisme") and it is probable that group belonging was to some extent based on the "pillar" one belonged to, Catholic or socialist. Partner selection might have been limited to those groups and so led to heterogamy by social origin, since social origin became relatively less important, or rather more difficult to combine with partner selection based on one's "pillar", just as group belonging based on geographical origin to some degree dominated partner selection in Tilleur and Liège. In short, the impression of openness observed in Aalst may be undermined by other societal rifts which are not revealed by the data presented here.

\section{The villages}

Before we discuss the differences among the villages and their evolution over time, we must briefly point to the difference between the cities and the villages. In Table 5 we saw that there was a big difference in absolute homogamy between the cities and the villages: in the villages the majority of marriages were homogamous, while in the cities that was not so, which is not surprising given the presence of large groups of farmers in the villages.

The differences between the villages are analysed in a logistic regression analysis presented in Table io. Compared with the Ardennes (model 1C), there was a higher level of homogamy in Bierbeek, while in Pays de Herve and Appelterre heterogamy was more common (although not significantly so). The pattern is dominated by the group sizes, in particular of farmers, absolute heterogamy being highest in the Pays de Herve, where the number of farmers was lowest. But there is more: the difference in heterogamy was not especially large (compared with Appelterre, 6 per cent, and with the Ardennes, 9 percent), while the difference in the percentage of farmers was 20 per cent or more. In Bierbeek the level of heterogamy was lowest, although the number of farmers was the same as in Appelterre or the Ardennes. 
Table 9. Logistic regression analysis of the chance of marrying heterogamously according to social origin (Flemish cities, I800-1913)

\begin{tabular}{|c|c|c|c|c|c|c|}
\hline & \multicolumn{2}{|c|}{ Model 1A } & \multicolumn{2}{|c|}{ Model 2A } & \multicolumn{2}{|c|}{ Model 3A } \\
\hline & Sig. & $\operatorname{Exp}(B)$ & Sig. & $\operatorname{Exp}(B)$ & Sig. & $\operatorname{Exp}(B)$ \\
\hline \multicolumn{7}{|l|}{ Period } \\
\hline $1800-1850$ & 0.001 & 0.578 & 0.006 & 0.636 & 0.021 & 0.673 \\
\hline $1851-1873$ & 0.015 & 0.670 & 0.031 & 0.699 & 0.153 & 0.782 \\
\hline $1874-1890$ & 0.002 & 0.629 & 0.006 & 0.657 & 0.381 & 0.867 \\
\hline \multicolumn{7}{|l|}{$1891-1913$ (ref.) } \\
\hline \multicolumn{7}{|l|}{ Location } \\
\hline Leuven & 0.369 & 0.900 & 0.571 & 0.935 & 0.407 & 0.903 \\
\hline Ghent & 0.363 & 0.899 & 0.582 & 0.936 & 0.313 & 0.884 \\
\hline Aalst (ref.) & & & & & & \\
\hline Group size & 0.000 & 0.973 & 0.000 & 0.971 & 0.000 & 0.949 \\
\hline \multicolumn{7}{|l|}{ Location $*$ Period } \\
\hline Leuven by $1800-1850$ & 0.029 & 1.549 & 0.050 & 1.492 & 0.064 & 1.471 \\
\hline Leuven by $1851-1873$ & 0.554 & 1.133 & 0.533 & 1.143 & 0.963 & 1.010 \\
\hline Leuven by $1874-1890$ & 0.289 & 1.238 & 0.369 & 1.200 & 0.600 & 0.895 \\
\hline Ghent by $1800-1850$ & 0.001 & 1.980 & 0.005 & 1.828 & 0.012 & 1.735 \\
\hline Ghent by $1851-1873$ & 0.225 & 1.295 & 0.298 & 1.251 & 0.538 & 1.146 \\
\hline Ghent by $1874-1890$ & 0.015 & 1.653 & 0.024 & 1.599 & 0.348 & 1.227 \\
\hline Occupational mobility & & & 0.000 & 1.443 & 0.000 & 1.464 \\
\hline \multicolumn{7}{|l|}{ Occupational immobility (ref.) } \\
\hline \multicolumn{7}{|l|}{ Migrant status groom } \\
\hline \multicolumn{7}{|l|}{ Native (ref.) } \\
\hline Rural migrant & & & 0.324 & 0.886 & 0.658 & 0.946 \\
\hline Non-rural migrant & & & 0.398 & 1.107 & 0.286 & 1.138 \\
\hline Foreigner & & & 0.757 & 1.075 & 0.510 & 1.169 \\
\hline Unknown & & & 0.690 & 1.155 & 0.496 & 1.285 \\
\hline Walloon migrant & & & 0.057 & 0.735 & 0.147 & 0.789 \\
\hline \multicolumn{7}{|l|}{ Migrant status bride } \\
\hline \multicolumn{7}{|l|}{ Native (ref.) } \\
\hline Rural migrant & & & 0.886 & 0.983 & 0.919 & 0.988 \\
\hline Non-rural migrant & & & 0.319 & 0.891 & 0.339 & 0.894 \\
\hline Foreigner & & & 0.508 & 0.844 & 0.539 & 0.853 \\
\hline Unknown & & & 0.736 & 0.883 & 0.800 & 0.909 \\
\hline Walloon migrant & & & 0.217 & 0.798 & 0.255 & 0.811 \\
\hline Geographically heterogamous & & & 0.000 & 1.360 & 0.000 & 1.341 \\
\hline \multicolumn{7}{|c|}{ Geographically homogamous (ref.) } \\
\hline \multicolumn{7}{|c|}{ Parents groom present } \\
\hline \multicolumn{7}{|l|}{ Parents not present (ref.) } \\
\hline Parents present & & & 0.000 & 1.616 & 0.000 & 1.463 \\
\hline No information & & & 0.618 & 1.181 & 0.844 & 1.069 \\
\hline \multicolumn{7}{|l|}{ Parents bride present } \\
\hline \multicolumn{7}{|l|}{ Parents not present (ref.) } \\
\hline Parents present & & & 0.501 & 0.928 & 0.489 & 0.926 \\
\hline No information & & & 0.877 & 1.053 & 0.947 & 1.022 \\
\hline \multicolumn{7}{|l|}{ Social origin groom } \\
\hline Higher managers and profess & nals $(1$ & $+2)$ & & & $\begin{array}{r}0.000 \\
(C\end{array}$ & $\begin{array}{c}0.420 \\
\text { ntinued }\end{array}$ \\
\hline
\end{tabular}


Table 9. Continued

\begin{tabular}{|c|c|c|c|c|c|c|}
\hline & \multicolumn{2}{|c|}{ Model 1A } & \multicolumn{2}{|c|}{ Model 2A } & \multicolumn{2}{|c|}{ Model 3A } \\
\hline & Sig. & $\operatorname{Exp}(B)$ & Sig. & $\operatorname{Exp}(B)$ & Sig. & $\operatorname{Exp}(B)$ \\
\hline Lower managers and profess & nals, $\mathrm{cl}$ & erical and & sales ( & $+4+5)$ & 0.388 & 1.108 \\
\hline Skilled workers $(6+7)$ & & & & & 0.000 & 1.856 \\
\hline Farmers (8) & & & & & 0.022 & 0.753 \\
\hline Lower-skilled workers (9) & & & & & 0.000 & 1.677 \\
\hline $\begin{array}{l}\text { Farm workers }(10+12) \\
\text { Unskilled (11) (ref.) }\end{array}$ & & & & & 0.562 & 1.169 \\
\hline Constant & 0.000 & 4.053 & 0.000 & 2.169 & 0.000 & 3.047 \\
\hline
\end{tabular}

Model information:

Model I A: $\mathrm{N}=5379$; model fit: $\mathrm{chi}^{2}=$ I I 5.5; $\mathrm{p}=0.000$; Nagelkerke $\mathrm{R}^{2}=0.029$.

Model 2A: $\mathrm{N}=5379 ;$ model fit: $\mathrm{chi}^{2}=204.6 ; \mathrm{p}=0.000$; Nagelkerke $\mathrm{R}^{2}=0.052$.

Model 3A: $\mathrm{N}=5379$; model fit: $\mathrm{chi}^{2}=330.9 ; \mathrm{p}=0.000$; Nagelkerke $\mathrm{R}^{2}=0.083$.

After controlling for group sizes (model 1B), we can see that the level of heterogamy was much lower in Pays de Herve than in the Ardennes. The higher level of absolute heterogamy measured in Pays de Herve was the result only of the relatively small number of farmers, meaning that at the level of daily experience as reflected in the level of absolute heterogamy we see societal openness caused by the presence of a large number of skilled and lower-skilled workers, such as those in the textile industry. Nonetheless, preference is strong for a partner from the same social origin, as is shown by controlling for the effect of group sizes.

In model 2C we add variables. Migrant grooms were more likely to marry heterogamously. After controlling for group sizes, the effect disappears (model 2B). The reason for that is the relationship between the number of migrants and the number of farmers (see above). Migration altered social structure, which resulted in more heterogamy. There is no similar effect to be seen in the migration status of brides. In the villages occupational immobility was related to homogamy, but that does not explain the lower level of heterogamy in Bierbeek and Pays de Herve (model 2B).

As far as the evolution of heterogamy is concerned, in general there was a higher level of heterogamy from I 874-i 890 than in the first half of the nineteenth century (Table IO, model 1C), but after controlling for group sizes we do not find any period effect (model 1B). Furthermore, Table 5 showed that the evolution of heterogamy was quite different in the villages. Only in the Ardennes was there a consistent increase in absolute heterogamy.

To examine the evolution of heterogamy in more detail, we applied a logistic regression analysis separately to each village (Table II). In Bierbeek there was no rise in absolute heterogamy but the chance of 


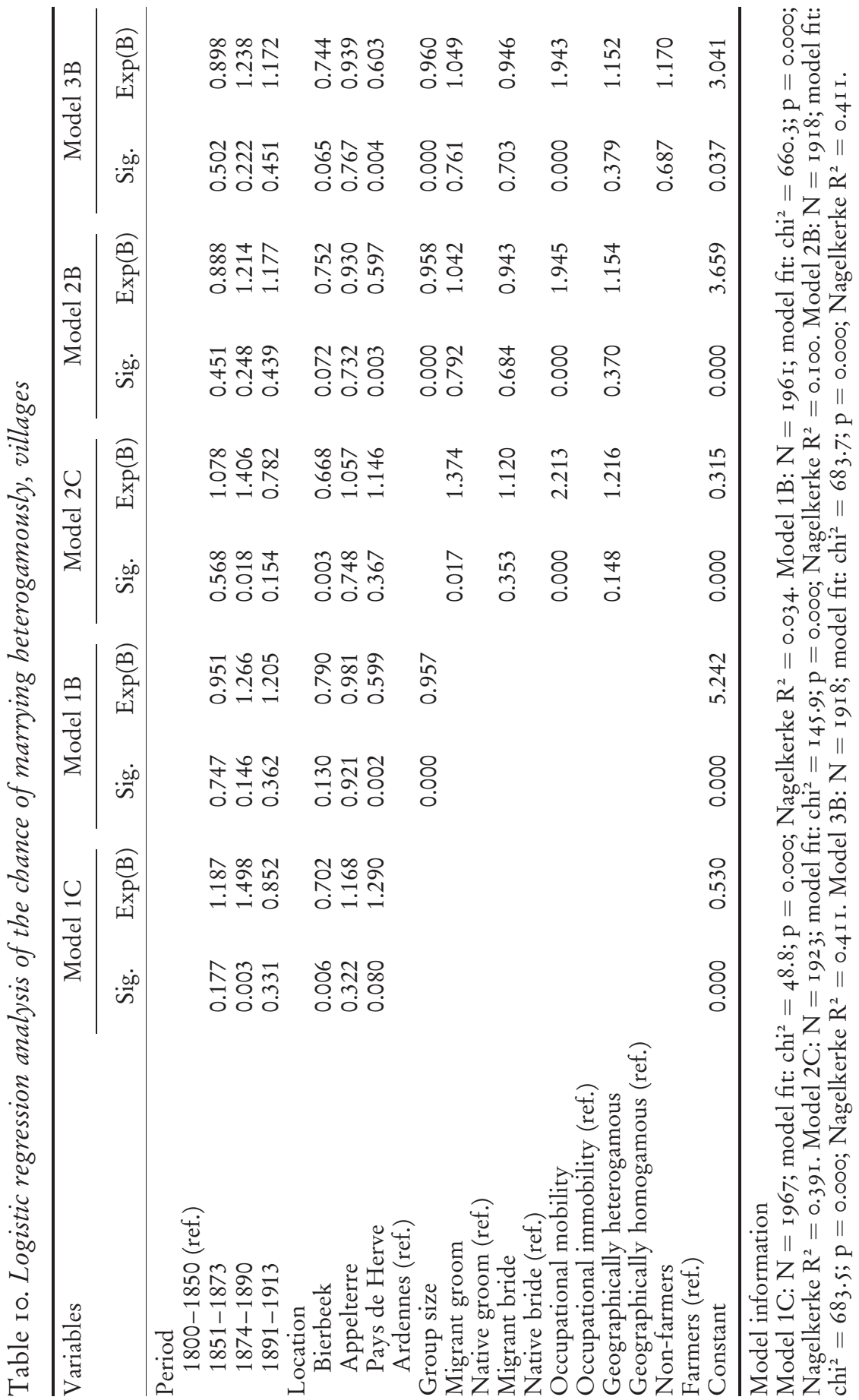




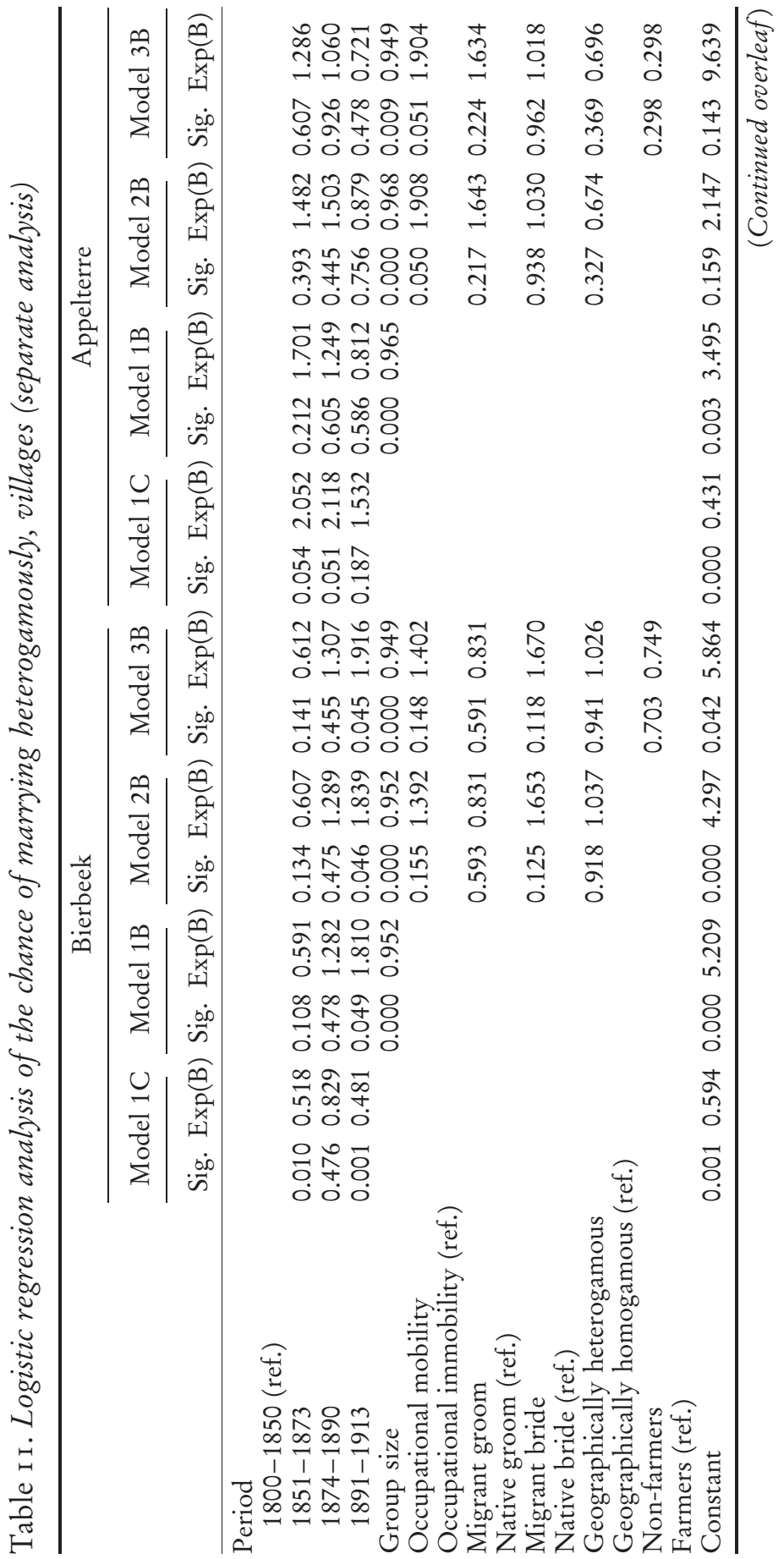




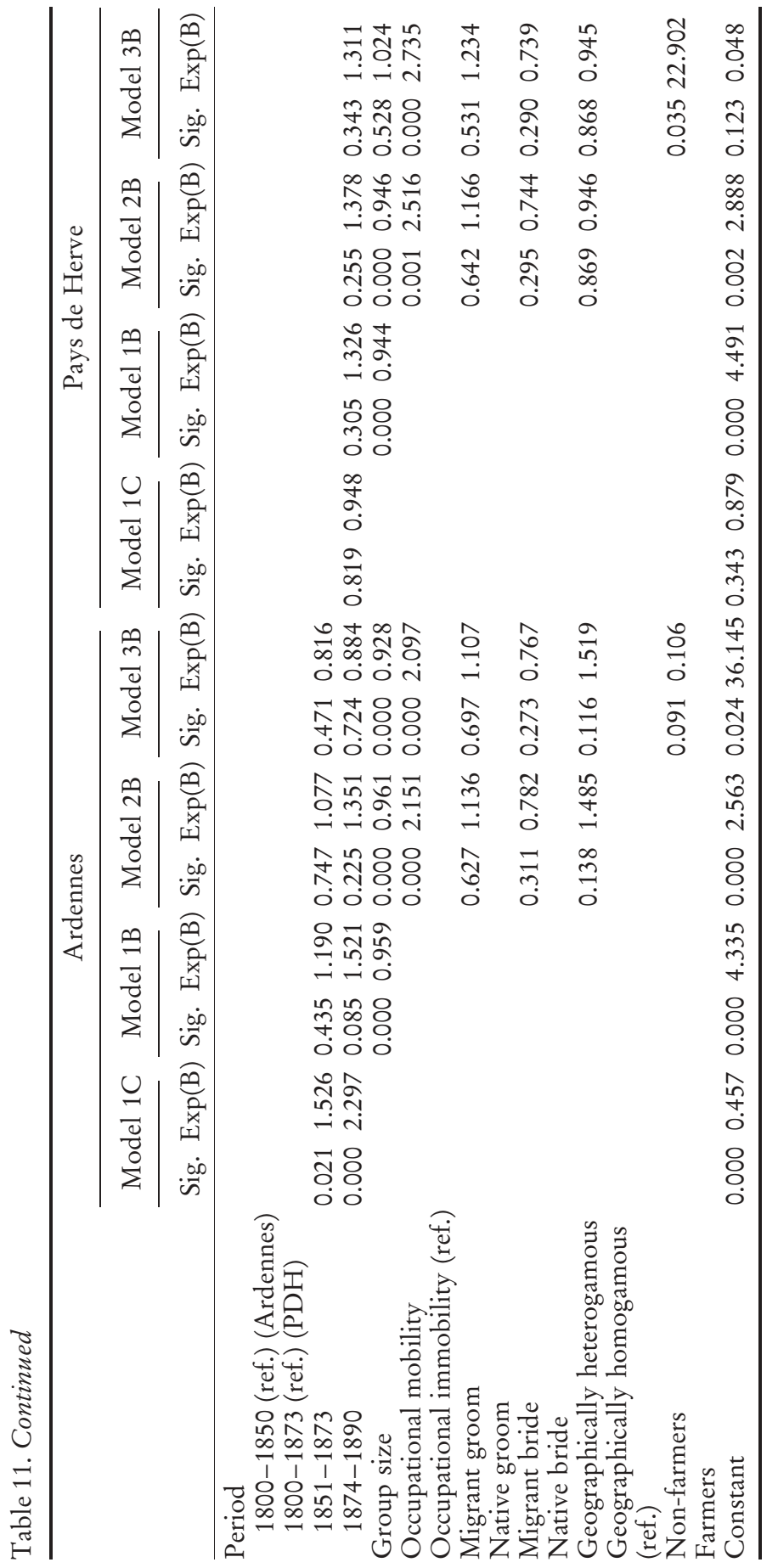


ㅇ்ㅎ்

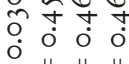

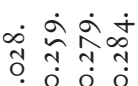

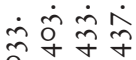

- $\dot{2} \tilde{\approx} \tilde{\sigma}$

|| $\|$ || $\|$

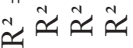

o.

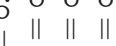

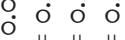

ठํ.

ary

$x^{2} \stackrel{2}{2} \underset{2}{2}$

|| || || $\|$

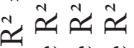

幽 o 0

붕

ox $x \rightarrow y$

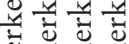

竞

00000

艺艺艺

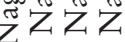

œ ô ô

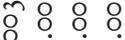

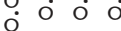

|| || || ||

$\ln 2 \pi$

程访

$\dot{n} \dot{\sim} \dot{n}$

$\approx \tilde{\pi} \approx \tilde{\pi}$

\|\|\|\|

牙 $=$

究艺艺

œ人

$\begin{array}{rlll}\Re & 0 & 0 & 0 \\ & 0 & 0 & 0\end{array}$

ஊó ô

$\begin{array}{llll}0 & 0 \\ 0 & 0 & 0 & 0\end{array}$

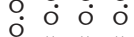

$\|$ \| $\|$

an 2

|| || ||

0 an 0

证的和

वंध भुषं

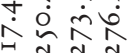

|| || || ||

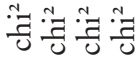

|| || || ||

$\therefore: \exists \cdot x^{2} \cdot x^{2}$

苂苂岀苂

릉 㐘毒:

岀岀苛苂

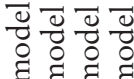

च च च

ô $\ddot{0} \ddot{q} \ddot{q}$

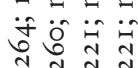

|| || ||

|| || || ||

乙二乙乙

乙乙乙二

$\ddot{U} \ddot{\oplus} \ddot{\oplus} \ddot{n}$

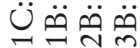

的的的的

ベ゚ス

|| || || ||

乙二乙Z

$\ddot{s} \cup \ddot{\theta} \ddot{\theta}$

\|\|$^{4} \approx 2$

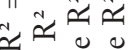

o $y$

牙

000

串艺 Z

ZZ о

$\begin{array}{llll}\dddot{a} & 0 & 0 & 0 \\ \infty & 0 & 0 & 0 \\ \infty & 0 & 0\end{array}$

\begin{tabular}{llll}
$\infty$ & 0 & $\dot{0}$ & 0 \\
\hline & 0 & $\|$ & $\|$
\end{tabular}

$\| n$

2.

ำ

|| || || ||

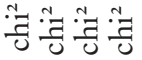

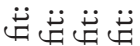
『๘丁 ० $\ddot{\infty} \cdots \cdots$ กNำ

. || || || || ZZZZ IU $\ddot{\sim} \ddot{\oplus}$

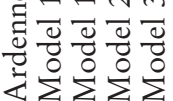
元 क 7 -

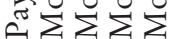


marrying heterogamously, when the figures are controlled for group sizes, did increase during I89I-I9I3 compared with the first half of the nineteenth century (model $1 \mathrm{~B}$ ). Although occupational immobility for example decreased, this rise in heterogamy is not related to the variables introduced in model 2B. In the Ardennes, the increasing level of absolute heterogamy (model 1C) is connected to the decline in the number of farmers (model 1B). The high level of absolute heterogamy from I 874I 890 is no longer significant at the o.05 level if the model controls for group sizes, but the parameter remains high and significant at the 0.10 level. Adding occupational immobility, migration and geographical homogamy reduces the parameter even further (no longer significant, model 2B). That is not unexpected given that occupational immobility and the by-product effect decreased after I 873 (see above). In Appelterre and the Pays de Herve there was no rise in heterogamy, even after adding the extra variables. Occupational mobility too in those villages was an important determinant of heterogamy.

The main conclusion is that there was no general rise in heterogamy in the villages, and the two villages which did show an increase took a different "path". In the Ardennes, heterogamy increased mainly because of the declining number of farmers, the decline of occupational immobility and the decline of the by-product effect; while in Bierbeek after controlling for group sizes we see that heterogamy increased but was linked neither to occupation nor migration-related factors.

\section{GENERAL CONCLUSION}

In this analysis we examined the effect of migration and occupational identity on partner selection according to social origin. A clear, general, consistent effect of migration was not found. The role of migration is probably more complicated than we have presented it to be in this research, but all the same a specific effect was found. Avoidance of the marginal group of Flemish migrants led to increased societal openness with regard to social origin. In Liège and Tilleur in the second half of the nineteenth century the number of strangers increased, both Flemish and foreigners. The native Walloon population, not very keen on intermingling with them, were exposed to an increasing difficulty finding partners of the same social origin in the "native marriage market".

We also found support for the idea that occupational identity is an important factor in partner selection. Sons having the same occupation as their father had a greater chance of marrying homogamously. But to this must be added that in industrial sectors high levels of intergenerational occupational immobility were observed as well and the lack of any decrease in intergenerational immobility is perhaps a reason why there was no general increase in societal openness during the course of industrializa- 
tion. An interesting finding is the decrease in heterogamy in Verviers during I 874-1 890. Early lower-class formation succeeded the urban crisis in the first half of the nineteenth century and that transition was accompanied by a decrease in societal openness. In our interpretation, that reflects the increasing use of modern occupational identities as a means to impart structure to social life and social bonds and to claim social dignity.

In addition, the relationship between migration, occupational identity and class structure did have effects on partner selection. Migration sometimes changed social structure and consequently affected partner selection, which is clearly seen in some of the villages. There was possibly a by-product effect as well. The association between geographical and social origin and the sometimes only moderate tendency to marry homogamously according to geographical origin also caused homogamy by social origin, but that did not significantly affect the main trend in homogamy. Whether the combination of specific geographical and social positions led to increased feelings of group belonging was difficult to demonstrate because there were no large social groups with a distinctive migrant status. Consequently, we believe that factor was probably not responsible for dramatic changes in the pattern of partner selection.

As a result of the interplay of these factors, we observed in this analysis of partner selection in Belgian cities and villages different patterns of homogamy according to social origin. We do not claim that our interpretation of these patterns cannot be refined. More detailed research will add more information about these complex issues, but at least one general conclusion emerges: it is difficult to interpret all these diverse patterns in terms of modernization. In our opinion, the historical context creates a complicated set of conditions, reflected in differences in the type and strength of migration and in the sectoral composition and evolution of the local economy, and context influences partner selection. Of course, that does not exclude the possibility that in a later phase a coherent pattern did emerge. In Aalst for example, there was an increase in heterogamy but only after 1890 , in a period when industrialization was expanding and a modern mass labour movement was born - a situation very different from that in Verviers before 1890.

Finally, we discuss some specific implications of this study. First, it is difficult and maybe in some cases misleading to look at a country as a whole. That is true even for the countryside alone. Villages vary greatly in terms of migration, the number of farmers or the different profile of migrants and natives. Those factors influence partner selection, so it might be advisable to use the variables formally in analysis. Second, partner selection is not determined only by an individual's or his family's social power, status, achievements, and so forth. As shown by the role of early class formation in Verviers and the position of the Flemish in Liège and 
Tilleur, group belonging too is important as it shapes social life and contacts and thereby affects partner selection. Not only are groups related by occupation important, but so too are groups based on geographical origin; and possibly religion. The formal introduction of these considerations can definitely help to explain partner selection according to social origin. 